UNIVERSIDADE DE SÃO PAULO

ESCOLA DE ENFERMAGEM

\title{
ANSIEDADE E MEDO NO PRÉ-OPERATÓRIO DE CIRURGIA CARDÍACA: INTERVENÇÃO DE ENFERMAGEM NA ABORDAGEM PSICOSSOCIAL
}

MARIA DENISE LEON

São Paulo

2007 


\title{
MARIA DENISE LEON
}

\section{ANSIEDADE E DO MEDO NO PRÉ-OPERATÓRIO DE CIRURGIA CARDÍACA: INTERVENÇÃO DE ENFERMAGEM NA ABORDAGEM PSICOSSOCIAL}

\author{
Dissertação de Mestrado \\ apresentada ao Programa de Pós- \\ Graduação em Enfermagem na \\ Saúde do Adulto (PROESA) da \\ Escola de Enfermagem da \\ Universidade de São Paulo para a \\ obtenção do título de mestre.
}

Orientadora: Profa. Dra. Vilanice Alves de Araújo Püschel

São Paulo 


\section{Catalogação na Publicação (CIP) \\ Biblioteca "Wanda de Aguiar Horta" \\ Escola de Enfermagem da Universidade de São Paulo}

Leon, Maria Denise.

Ansiedade e medo no pré-operatório de cirurgia cardíaca: intervenção de enfermagem na abordagem psicossocial. / Maria Denise Leon. - São Paulo, 2007.

$110 \mathrm{p}$.

Dissertação (Mestrado) - Escola de Enfermagem da Universidade de São Paulo.

Orientadora: Prof $^{a}$ Dr $^{a}$ Vilanice Alves de Araújo Püschel.

1. Ansiedade 2. Enfermagem perioperatória 3. Intervenção da enfermagem (cirurgia) 4. Enfermagem em centro cirúrgico 5.Coração (cirurgia). I. Título. 
Para Luiz

Meu esteio, meu incentivo, minha vida. 


\section{Agradecimentos}

Às enfermeiras Elaine e Eliana, que me disponibilizaram recursos, acreditaram no meu trabalho e me incentivaram do começo ao fim.

À Professora Estela, que me abriu as portas da universidade e esteve sempre disponível.

Às professoras Doris, Terezinha e Fernanda que me apontaram caminhos; minhas primeiras incentivadoras.

À professora Vilanice, que me mostrou novos caminhos.

À colega Karine que teve colaboração importante no final do trabalho.

À D. Marilene e Patrícia, que flexibilizaram meus plantões no Hospital das Clínicas, me auxiliando no cumprimento dos prazos.

Aos meus familiares que tiveram paciência e assumiram algumas tarefas para que eu pudesse me dedicar a este estudo.

À grande amiga Cris, que me auxilia nos raciocínios e não me permite esmorecer.

Ao Instituto Dante Pazzanese de Cardiologia, que me abriu as portas sem ressalvas, para esta pesquisa.

Às pessoas que direta ou indiretamente contribuíram para a realização deste estudo; funcionários do Instituo Dante Pazzanese e da Escola de Enfermagem da Universidade de São Paulo.

E principalmente, a todos os pacientes participantes desta pesquisa, que me receberam com carinho. Espero ter compreendido suas emoções e ter realizado não apenas pesquisa, mas também assistência de enfermagem.

\section{Muito obrigada!}


"Só se vê bem com o coração. O essencial é invisivel aos olhos". 


\section{LISTA DE TABELAS}

Tabela 1 - Distribuição dos sujeitos da pesquisa do grupo de intervenção e de controle, segundo sexo, escolaridade, estrato sócio-ocupacional e idade. Hospital especializado em cardiologia, São Paulo. 2006.

Tabela 2 - Média dos níveis de ansiedade e medo da amostra total e dos dois grupos (intervenção e controle) no primeiro momento (baseline). Hospital especializado em cardiologia. São Paulo, 2006.

Tabela 3 - Comparação dos indicadores de resultados entre os grupos de intervenção e controle nos três momentos de avaliação. Hospital especializado em cardiologia, São Paulo, 2006.

Tabela 4 - Comparação dos indicadores de resultados nas três avaliações nos grupos intervenção e controle. Hospital especializado em cardiologia, São Paulo, 2006

\section{LISTA DE FIGURAS}

Figura 1 - (A) Nível de ansiedade do grupo intervenção versus controle.

Figura 1 - $\quad$ (B) Nível de medo do grupo intervenção versus controle.

Figura 2 - Esquema representacional da vivência das dinâmicas 74

Figura 3 - Esquema representacional do significado da atividade de orientação grupal.. 


\section{RESUMO}

Leon MD. Ansiedade e medo no pré-operatório de cirurgia cardíaca: intervenção de enfermagem na abordagem psicossocial [dissertação]. São Paulo: Escola de Enfermagem, Universidade de São Paulo; 2007.

O investimento dessa pesquisa foi colocar em evidência os sentimentos de ansiedade e medo, encontrados em pessoas que se submeteriam à cirurgia de revascularização do miocárdio, por meio da aplicação de uma estratégia de intervenção grupal, na abordagem psicossocial. Os objetivos foram: identificar os níveis de ansiedade e medo nas pessoas que iriam se submeter à cirurgia de revascularização do miocárdio (RM); implementar uma estratégia de orientação grupal na visita pré-operatória, na abordagem psicossocial, para as pessoas que apresentaram medo e ansiedade no préoperatório de cirurgia de RM; comparar os níveis de ansiedade e medo entre as pessoas que receberam as orientações tradicionais da instituição e aquelas que participaram da estratégia de orientação grupal na visita préoperatória; apreender o significado das orientações pré-operatórias segundo a percepção das pessoas participantes dos grupos de intervenção. A pesquisa, de natureza quantitativa e qualitativa, foi realizada em um hospital especializado em cardiologia, no município de São Paulo no período de abril a agosto de 2006. Das pessoas abordadas para avaliação (109), 60 participaram efetivamente do estudo, sendo 30 no grupo de intervenção e 30 no grupo controle. Foi realizado um ensaio clínico controlado randomizado. Os dados foram analisados por meio de análise estatística e de análise de conteúdo, segundo Bardin. No grupo de intervenção foram utilizadas dinâmicas grupais para promover um ambiente relaxante e possibilitar aberturas para livre expressão das pessoas participantes. A maioria dos participantes era do sexo masculino, com Ensino Fundamental Incompleto, com nível sócio-econômico médio, com idade média de 62,02 anos. Verificou-se que as pessoas que participaram do grupo de intervenção tiveram redução nos níveis de ansiedade e o medo de forma clínica e estatisticamente significantes. As dinâmicas proporcionaram um momento lúdico e expressivo, além do significado cognitivo/afetivo e relacional, sendo alcançada. a segurança e a tranqüilidade que levaram à redução da ansiedade e do medo. Os resultados indicam que as orientações préoperatórias realizadas de forma grupal, na abordagem psicossocial, produzem resultados efetivos e, portanto, recomenda-se que essa estratégia seja implementada nas instituições hospitalares.

Palavras-chave: Enfermagem de centro cirúrgico, Enfermagem perioperatória, Ansiedade. 


\begin{abstract}
Leon MD. Anxiety and fear in cardiac surgery pre-operative: nursing intervention in psychosocial approach [dissertation]. São Paulo: Escola de Enfermagem, Universidade de São Paulo; 2007.

This research is aimed at highlighting the importance of feelings such as anxiety and fear in those who are to undergo myocardial revascularization surgery $(\mathrm{RM})$, and the adoption of a psychosocial approach by which a strategy of group intervention is used. Aiming at identifying the levels of anxiety and fear in those patients, a strategy of group guidance during the pre-surgery round was adopted, using a psychosocial approach, comparing the levels of anxiety and fear in those who received traditional institutional guidance, and those who took part in the group guidance pre-surgical session, and also at comprehending the meaning of the pre-surgical guidance in the perception of the intervention group participants. This research is of a quantitative and qualitative nature, and was conducted in a specialized cardio hospital, in the city of Sao Paulo, in the period between April and August 2006. Out of the 109 people approached for assessment, 60 took an effective participation in the study, of which 30 were in the intervention group and 30 in the control group. A controlled, random clinical rehearsal was performed. The data was analyzed statistically and content wise, in accordance to Bardin. With the intervention group, group dynamics were applied so as to promote a relaxing, friendly environment, and allow for the participants' free expression. Most of the subjects in this group were male, with incomplete lower education, average socio-economic class, and 62,02 years old on average. It was noted that this group subjects had their levels of anxiety and fear lowered, in a statistically significant manner. The dynamics provided them with more than only a playful, expressive moment; they had a cognitive/affectionate, relational significance, through which security and tranquility were achieved, and, as a result, levels of anxiety and fear were reduced. Results indicate that group pre-surgical guidance in a psychosocial approach produces effective results, and is thus recommended for undertaking in hospital.
\end{abstract}

Key-words: Operating room nursing, Perioperative nursing, Anxiety. 


\section{SUMÁRIO}

1

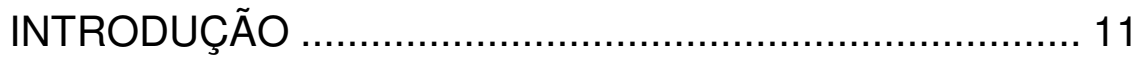

1.2 Ansiedade e medo no pré-operatório ................................... 13

1.3 A cirurgia cardíaca......................................................... 18

1.4 Assistência ao paciente cirúrgico ........................................ 20

1.5 A visita pré-operatória..................................................... 25

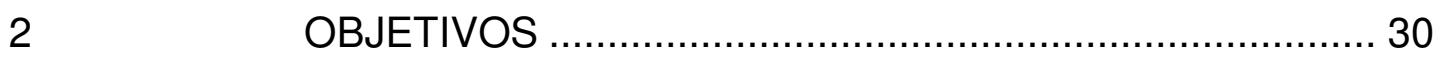

3 REFERENCIAL TEÓRICO METODOLÓGICO.................. 31

3.1 Referencial teórico........................................................... 31

3.2 Referencial metodológico ................................................... 36

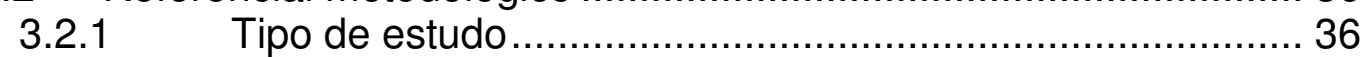

3.2.2 Local do Estudo ...................................................... 38

3.2.3 Sujeitos do estudo ..................................................... 40

3.2.4 Procedimento de coleta de dados ................................... 41

3.2.5 Método de abordagem do grupo de intervenção ............... 45

3.2.6 Aspectos Éticos .......................................................... 48

3.2.7 Análise dos dados ................................................... 49

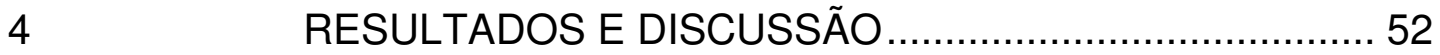

4.1 Caracterização dos sujeitos do estudo .................................... 54

4.2 Descrição e análise das dinâmicas .......................................... 60

4.3 Níveis de ansiedade e de medo nos períodos pré-operatório mediato, imediato e pós-operatório ..............................................6 65

4.4 Efetividade da intervenção nas orientações grupais ...................6 67

4.5 Limitações do estudo....................................................... 71

4.6 A vivência das dinâmicas utilizadas para a orientação préoperatória no grupo de intervenção............................................. 73

4.7 Significado da estratégia de orientação grupal na perspectiva dos participantes ..................................................................................... 78

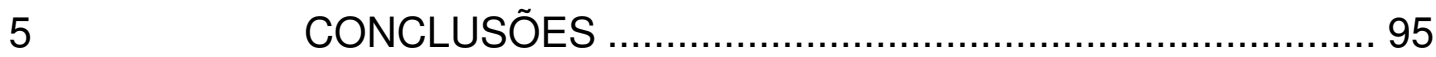

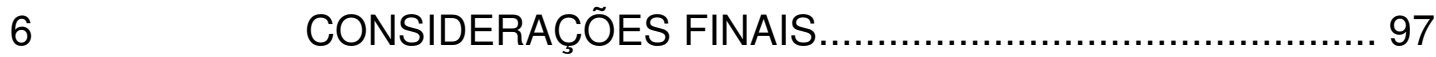

Referências Bibliográficas ....................................................... 103 


\section{ANSIEDADE E MEDO NO PRÉ-OPERATÓRIO DE CIRURGIA CARDÍACA: INTERVENÇÃO DE ENFERMAGEM NA ABORDAGEM PSICOSSOCIAL}

1 INTRODUÇÃO

\subsection{Justificativa}

Em minha experiência de 10 anos como instrumentadora de cirurgia cardíaca, dentro de uma instituição especializada, sempre ficava incomodada com a expressão facial de muitos pacientes no momento em que estavam na sala de cirurgia sendo preparados para começar 0 procedimento cirúrgico. Freqüentemente estas pessoas demonstravam sentimentos de tensão, medo e ansiedade bastante fortes, que eram percebidos nitidamente em seus rostos, em suas lágrimas e em suas palavras tímidas e sedentas por uma troca afetiva com as pessoas que estavam em sua volta. Era uma situação difícil a ser enfrentada. Muitas vezes desconhecida e assustadora, sendo que boa parte delas sentiam suas vidas ameaçadas. Meu ímpeto de ajudá-los é o que me motivou a começar esta pesquisa como parte do investimento em minha formação profissional.

Durante este período, fiz o curso de graduação em enfermagem, que foi um estímulo ainda maior para buscar intervir nesta situação, pois em campos de prática percebi que a relação de muitos enfermeiros com as pessoas internadas era, geralmente, distante e fria. Esta questão me incomodava bastante, sendo que alguns artigos que lia era colocada em evidência a "fuga" dos enfermeiros no enfrentamento de questões emocionais dos pacientes. Isto me levou a crer que a assistência de enfermagem nem sempre tem sido prestada ao ser multidimensional.

Como enfermeira, dentro da sala cirúrgica, não poderia continuar simplesmente assistindo pacientes ansiosos, cheios de dúvidas e medos do desconhecido, sem algum tipo de intervenção que amenizasse tais reações. 
Assim, minha inquietação levou a investir neste estudo à procura de um modo de intervenção nas pessoas que se submeteriam ao procedimento cirúrgico. Passei então a pesquisar sobre o medo e a ansiedade do paciente cirúrgico e a assistência prestada a ele. A visita préoperatória de enfermagem foi o maior enfoque desta pesquisa, pois este constitui momento importante de contribuição para o melhor enfrentamento do processo cirúrgico pelos pacientes, bem como para melhorar a qualidade de assistência do enfermeiro e possibilitar uma redução da ansiedade e do medo. 


\subsection{Ansiedade e medo no pré-operatório}

Segundo Mc Reynolds ${ }^{1}$ a ansiedade é uma das mais fortes e características emoções do ser humano. É um sentimento desagradável e difícil de definir de forma rigorosa. Foi assunto de intensa investigação durante muitas décadas, sendo que sua significação tanto na psiquiatria quanto na medicina interna tornou-se solidamente estabelecida.

Spielberger ${ }^{2}$ trabalha com duas situações de ansiedade denominando-as de traço e estado de ansiedade. $O$ traço significa a percepção individual que leva a diferentes reações à situações vivenciadas. O tipo de comportamento de cada indivíduo é influenciado por experiências próprias que os levam a reagir de determinada forma. $\mathrm{O}$ termo estado de ansiedade é o que será discutido neste estudo é definido por Spielberger ${ }^{2}$ como uma reação a uma dada situação tensa e ameaçadora. Este sentimento transparece através de alterações fisiológicas tais como: tremores, palpitações e vertigens; mas também por meio de alterações comportamentais como: apreensão, nervosismo e preocupação.

Estes termos também são citados por Mc Reynolds ${ }^{1}$ como "lugares-comuns" utilizados pelas pessoas em geral para se referirem à ansiedade. Ele acrescenta ainda tensão e stress.

Existem casos de superprodução de açúcar no sangue, levando a diabetes e até condições de instabilidades cardíacas como manifestação somática de ansiedade e medo. Pode-se citar também como manifestações físicas: hiperventilação, náusea, diarréia, boca seca, insônia, inapetência e fraqueza ${ }^{1,2}$.

Para $\mathrm{May}^{3}$, ansiedade é uma reação a algum tipo de destruição da existência do indivíduo ou daquilo que a identifica como existência. Como exemplos básicos disto temos a doença grave e a morte. 
Assim sendo, a finalidade da ansiedade é proteger-nos dos perigos que ameaçam a nossa existência ou nossos valores. A ansiedade não pode ser evitada, mas pode ser reduzida. Em níveis normais, a ansiedade pode ser utilizada como estímulo para aumentar a consciência, a vigilância, o gosto pela vida e a auto-proteção.

Este autor comenta que existem provas de que a ansiedade, os medos e os conflitos que foram excluídos da consciência são aqueles que têm a maior probabilidade de estar manifestado etiologicamente em doença. Os sintomas fisiológicos de ansiedade podem ser definidos como um mecanismo de defesa interior. $\mathrm{May}^{3}$ afirma que existem processos psicológicos automáticos que podem anular estes sintomas, quando o conflito e a própria ansiedade emergem para a consciência.

"Uma pessoa está subjetivamente preparada para enfrentar de um modo construtivo a ansiedade inevitável quando está convencida (consciente ou inconscientemente) de que valores a serem ganhos quando se vai em frente são maiores do que os obtidos pela fuga"3.

Conforme $\mathrm{Cabral}^{4}$, o medo é definido como um estado emocional inspirado pela presença real ou pressentida de um perigo concreto. É uma reação emocional aprendida com estímulos que denotam o advento da dor ou estímulos nocivos. A reação é adquirida através do condicionamento clássico.

$M^{3}{ }^{3}$ faz a distinção entre medo e ansiedade, quando menciona que o medo é uma reação a um perigo específico e a ansiedade é o sentimento de incerteza e impotência diante da ameaça. Ela é uma reação a uma ameaça a algum valor que o indivíduo considera essencial à sua existência como personalidade. As reações neurofisiológicas de um organismo em ocasiões de medo e de ansiedade podem ser totalmente diferentes, pelo fato de ocorrerem em níveis psicológicos distintos da personalidade. "Assim, a ansiedade é a reação básica e subjacente - o 
termo genérico; e o medo é a expressão da mesma capacidade em sua forma específica e objetivada."

Com essas definições é conveniente destacar que a ansiedade apresentada pelo paciente no período pré-cirúrgico é um tema importante e apontado como uma das causas de complicações pósoperatórias que podem ser minimizadas ou até evitadas, com a utilização do processo educativo aplicado no período pré-operatório ${ }^{5-25}$.

Existe um consenso na literatura, de que qualquer ato cirúrgico desencadeia um sentimento de ansiedade no indivíduo que vai ser submetido à intervenção $0^{1,5-7,8,9,11,13,15,17,18,19,21,22,25-30}$, o que, possivelmente seja decorrente de temores sobre o que poderá ocorrer no trans ou pósoperatório, ou mesmo que possa provocar futuras alterações no cotidiano da vida pessoal, profissional e familiar ${ }^{13-15,20,22,26,31-35}$.

Outro sentimento que surge nos pacientes, perante a perspectiva de uma cirurgia se refere ao medo. Os autores que pesquisaram este assunto encontraram: medo do desconhecido, da solidão, de ficar longe da família, da dor, da doença, da possibilidade de um câncer, de demonstrar o medo, de perder o autocontrole, da morte, da anestesia, do ato operatório, de não ser operado pelo médico escolhido, da recuperação pós-operatória, da permanência na Unidade de Terapia Intensiva, dos equipamentos da Unidade de Centro Cirúrgico, de não poder voltar logo às atividades profissionais e da possibilidade de deficiência física permanente ${ }^{6-10,12-}$ $15,17,20,23-26,32,35-38$.

Uma das formas para minimizar o medo é transmitir confiança às pessoas que se submeterão a um procedimento cirúrgico, além de proporcionar a elas condições para se sentirem confiantes. Sebastiani ${ }^{39}$ acrescenta que para isso deve haver disponibilidade dos enfermeiros não só para oferecer orientações simples e precisas sobre todo o tratamento, mas também para ouvir sentimentos e desmistificar fantasias. 
Peniche e Chaves ${ }^{40}$ comentam que a experiência de uma intervenção, como o procedimento anestésico cirúrgico, é visto como uma ameaça e exige um enfrentamento, desencadeando ajustes comportamentais e fisiológicos. Dizem ainda, que, há milênios que a resposta primitiva do ser humano para lutar ou fugir frente ao perigo continua sendo adaptativa, com todas as implicações bioquímicas e hormonais e que a "sobrevivência do homem depende de sua capacidade de mobilização dos mecanismos do corpo". Assim, enfrentar perigos sempre exige uma tomada de consciência, seguida de uma série de reações fisiológicas que nem sempre podem ser controladas pelo indivíduo, tal como taquicardia, urgência urinária ou sudorese, ou mesmo as reações de ansiedade e de medo.

O medo da morte é um dos grandes temores apresentados pelos pacientes. Casos de morte por problemas com a anestesia geral são bastante comentados pela mídia, principalmente quando envolvem pessoas famosas. Desta forma, qualquer paciente pode ter tido contato com este tipo de informação, o que pode causar insegurança para aqueles que terão que enfrentar uma situação cirúrgica utilizando este tipo de anestesia.

A própria inconsciência gerada pela anestesia geral significa para muitos uma aproximação com a morte, trazendo a sensação de "desaparecer dormindo"41. Além disso, o enfrentamento do desconhecido é uma situação que gera sentimentos de impotência e de dependência. Estes sentimentos podem desencadear respostas somáticas e emocionais, pela liberação de catecolaminas, o que pode se manifestar de diferentes formas nos diversos indivíduos, conforme Peniche e Chaves ${ }^{40}$.

Silva $^{33}$ acrescenta que o homem sempre reage de forma global às situações experienciadas, ou seja, sem conseguir separar as reações físicas das emocionais. É esperado que um indivíduo hospitalizado à espera de uma cirurgia esteja emocionalmente fragilizado e necessita de apoio. 
Byrne $^{42}$ afirma que do ponto de vista clínico, a ansiedade não implica em sobrevivência, mas ao contrário, em ameaça e sofrimento. Além disso, o grau de ansiedade depende das expectativas pessoais em relação às imposições sociais e culturais que determinam regras estruturais nas sociedades humanas.

É de se considerar, também, que o hospital, local onde predominantemente ocorre $\mathrm{o}$ ato cirúrgico, é um ambiente e impessoal, que pode gerar também ansiedade.

Outros aspectos que podem contribuir para o aumento da ansiedade e do medo, além dos já mencionados, se relaciona ao tipo e ao tamanho da cirurgia a ser realizada, as condições clínicas das pessoas ou o tipo de órgão acometido. Acredita-se que as cirurgias cardíacas, as realizadas para diagnóstico ou extirpação de tumores, as neurológicas, os transplantes, dentre outras, tenham grande potencial para gerar ansiedade, porém nesse trabalho será abordada somente a cirurgia cardíaca de revascularização do miocárdio. 


\subsection{A cirurgia cardíaca}

É do senso comum, que o coração é visto como símbolo de vida e sentimento. Apesar de a ciência ter comprovado que as emoções estão localizadas no cérebro, consolidou-se historicamente, a partir da filosofia de Aristóteles ${ }^{43}$ a fantasia romântica de que o coração é o dono das emoções. Porto ${ }^{44}$ cita o significado simbólico do coração como um arquétipo, enraizado em nosso inconsciente e influindo em nossa forma de perceber acontecimentos, principalmente as doenças que colocam em risco nossas vidas. O termo "arquétipo" é o que Jung ${ }^{45}$ define como "imagens primordiais" ou ainda "imagens coletivas" da nossa mente, que permanecem armazenadas no inconsciente e herdadas de uma história construída, não individualmente, mas pela própria humanidade.

Para Alexander ${ }^{46}$, quanto mais valorizado for o órgão operado, maior a ansiedade frente à cirurgia. Segundo Christopherson e Pfeiffer $^{7}$, a cirurgia cardíaca é a que possui maior potencial de gerar ansiedade, pois o coração é um órgão associado à vida, à morte e à geração de sentimentos.

Duarte $^{47}$ afirma que entre todos os tipos de cirurgia, a cardíaca é a menos tolerada psicologicamente. Seus estudos enfocam o papel das emoções nas complicações pós-operatórias deste tipo de cirurgia. Ele cita ainda que a negação da ansiedade nestes pacientes possa gerar predisposições a problemas clínicos no pós-operatório imediato.

Batiston, Pereira, Catão e Duarte ${ }^{48}$ comentam que pelo fato do coração representar simbolicamente a própria vida, a cardiopatia coloca o paciente de frente com a angústia e ansiedade geradas pelo medo da morte. Assim, em sua pesquisa eles afirmam que a ansiedade e a depressão são aspectos psicológicos fundamentais de serem pesquisados e trabalhados tecnicamente na atuação clínica junto ao paciente cardiopata cirúrgico. 
Segundo Svartman ${ }^{49}$, a própria descoberta da presença de uma cardiopatia freqüentemente causa uma crise emocional. Primeiro pelo confronto com a angústia de morte, já que o coração é considerado o "motor da vida". Segundo, pelo enfrentamento necessário aos novos limites impostos à sua vida prática, pela patologia e tratamento, incluindo o cirúrgico.

A pesquisa de $\mathrm{Khun}^{9}$, que se refere especificamente aos problemas encontrados no pré-operatório de cirurgia cardíaca cita: medo da anestesia "não pegar", do risco do coração não voltar a bater, da possibilidade do rompimento das pontes e de que o coração seja retirado do corpo durante a cirurgia. Os pacientes mencionam ainda preocupações com os familiares, devido ao temor de morrer e de deixar filhos pequenos.

Das cirurgias cardíacas, a de revascularização do miocárdio (RM) pode ser considerada a mais comum, representando quase metade do número total de cirurgias realizadas na instituição estudada.

Ela é utilizada como tratamento para a doença isquêmica do coração que é o tipo mais prevalente de doença cardiovascular. Isto porque as doenças do aparelho circulatório representam a principal causa de morte no Brasil como um todo e, também em todas as regiões separadamente (32\%). Atinge pessoas comumente acima de 40 anos, mas pode atingir também pessoas de uma faixa etária mais jovem.

A cirurgia de RM dura em média de 4 a 6 horas dependo da gravidade de cada caso e apesar de existiram novas técnicas que permitem realizá-la com o coração batendo, a maior parte delas ainda exige a instalação do aparelho de circulação extra-corpórea. 


\subsection{Assistência ao paciente cirúrgico}

De acordo com Silva; Rodrigues e Cesaretti ${ }^{50}$ são quatro os significados da cirurgia do ponto de vista do paciente: "ato de confiança, ato de aceitação ou submissão, invasão de intimidade e fator causal de medo".

Quando um tratamento cirúrgico é proposto a um paciente, este normalmente não tem competência técnica para avaliar a real necessidade de ser operado. Portanto, quando ele toma a decisão de enfrentar a cirurgia, está dando um voto de confiança à equipe cirúrgica e ao mesmo tempo se submetendo à todas as condições impostas pela situação. A pessoa que se interna numa instituição hospitalar para se submeter a um procedimento anestésico cirúrgico traz consigo expectativas e preocupações relacionadas à cirurgia e à sua evolução pós-operatória. Ao concordar em se submeter às condições apresentadas pelo serviço e pela equipe de saúde, a fim de alcançar um bom resultado.

Isto significa que existe uma relação de confiança entre paciente e equipe, o que exige competência técnica para que 0 procedimento ocorra com o mínimo de riscos, mas exige também a necessidade de se promover o preparo emocional do indivíduo. Os aspectos técnico e emocional devem ser tratados de forma conjunta e harmoniosa, a fim de que a competência da equipe multiprofissional juntamente com a colaboração do paciente alcancem a eficiência do tratamento cirúrgico.

Uma das estratégias que o enfermeiro poderia utilizar para amenizar a ansiedade e o medo seria proporcionar informações e promover o diálogo esclarecedor e o acolhimento das pessoas. Nesse sentido, a assistência ao paciente cirúrgico assume uma importância fundamental para a ação/intervenção profissional.

No entanto, muitos profissionais chegam a afirmar que não foram preparados no curso de graduação em enfermagem para fazer a abordagem dos problemas emocionais dos pacientes, além de não 
possuírem bases conceituais sólidas para realizar intervenções nesta área ${ }^{38}$. Silva $^{51}$ relata que os cursos de graduação em enfermagem e os de especialização dão grande ênfase às disciplinas das áreas biológicas, assim sendo, é comum enfermeiros terem dificuldades em adquirir conhecimentos nas áreas das ciências humanas, para poderem oferecer assistência integral. Esta autora menciona que o modelo biomédico visa à cura de um determinado órgão doente, mas não costuma levar em conta a totalidade do paciente, no que se refere à sua sensibilidade física e emocional.

A formação profissional nesse modelo não só contribui, mas muitas vezes é determinante para que, na prática profissional, muitas das informações dadas à pessoa que se submeterá a um procedimento cirúrgico estejam voltadas somente à abordagem técnica relacionada a procedimentos, equipamentos, condição após a cirurgia, tempo de permanência na Unidade de Terapia Intensiva. Embora estas informações sejam necessárias, nem sempre podem contribuir para a redução de ansiedades e de medo, ou, em alguns casos, até aumentá-los.

Santos; Luis ${ }^{35}$ também comentam que muitos enfermeiros deixaram de receber subsídios teóricos, nem foram orientados a compreender e valorizar o significado da experiência cirúrgica para os pacientes. Assim, estes têm dificuldades em lidar com os sentimentos desencadeados pelos procedimentos cirúrgicos. Portanto, segundo estas mesmas autoras, faz-se urgente uma transformação do profissional enfermeiro (de quem é solicitada grande habilidade técnica) numa pessoa apta a atender ao paciente em suas necessidades emocionais, para que 0 ato operatório possa ser menos traumatizante.

Castellanos, Jouclas e Gatto $^{52}$ enfatizam o perigo de se burocratizar a práxis da orientação ao paciente, tornando-a mecânica e reiterativa. Zago ${ }^{53}$ afirma que a comunicação do enfermeiro de centro cirúrgico tem sido inefetiva no processo educativo, pois se tornou "padronizada, fragmentada e rotineira, seguindo um padrão vertical, sem a preocupação de estabelecer uma relação empática com o paciente". 
O enfoque humanista vem produzindo mudanças marcantes para a enfermagem, redimensionando a prática com novas dimensões, sendo uma delas a atenção psicossocial em diferentes campos de atuação ${ }^{54}$. Considerando-se que enfermeiro é o profissional que mais tempo permanece ao lado da pessoa doente, ele tem mais oportunidades para observar e perceber suas reações, podendo assim, assumir as atividades de educação e de orientação ${ }^{33,53,55}$.

Segundo Capra $^{56}$, os enfermeiros desempenham um importante papel no processo de cura através do "contato" com os pacientes. Este autor comenta que os enfermeiros se encontram na vanguarda do movimento holístico, integrando os tratamentos da doença a um todo significativo através da orientação e do acompanhamento pessoal.

Mas, Cordeiro ${ }^{24}$ comenta que na nossa realidade hospitalar, o apoio psicológico tem sido prescrito de forma generalizada no planejamento da assistência de enfermagem. Há necessidade de se prescrever em detalhes o por que, a maneira e o momento de se prestar esta assistência.

"O estado psicológico de uma pessoa, evidentemente, não só é importante na geração da doença, mas também crucial para o processo de cura" ${ }^{56}$.

No estudo de Baggio, Teixeira e Portella ${ }^{19}$ que teve como objetivo identificar a percepção do paciente de cirurgia cardíaca acerca das orientações pré-operatórias fornecidas pela enfermagem, ficou destacado que a simples demonstração de sensibilidade do enfermeiro permite ao paciente expressar seus sentimentos e sentir como conforto a presença de pessoas humanas.

$\mathrm{Kubo}^{57}$ fez uma pesquisa com pacientes valvopatas e encontrou que $82,8 \%$ deles desejavam obter informações adicionais sobre 
sua doença e tratamento. Entre os $17,2 \%$ que referiram não querer tais informações, ficaram destacados os sentimentos de medo e negação.

Muitos autores comentam, que numa visita pré-operatória, o enfermeiro pode transmitir segurança aos pacientes, além de possibilitar uma satisfação profissional pelo estabelecimento de uma relação interpessoal com a pessoa doente $8,10,13-15,20,32$.

Castellanos, Jouclas e Gatto $^{52}$ citaram os problemas de enfermagem mais freqüentemente encontrados na fase trans-operatória, de acordo com pesquisa realizada em literatura, sendo que, a segurança emocional foi a necessidade básica mais afetada. Como segunda prioridade apareceu a segurança física.

Armelin $^{58}$ cita que os pacientes valorizam o relacionamento interpessoal com o enfermeiro, emergindo dele o apoio emocional como elemento do cuidar. Os cuidados na área instrumental ou técnica são esperados na hora certa e com habilidade, mas sem descartar o envolvimento afetivo do profissional durante a realização dos mesmos.

De modo geral, o que se constatou em toda a literatura pesquisada é que as recomendações para a realização de uma visita préoperatória estão baseadas em orientações sobre como os procedimentos irão ocorrer. É esperado que as pessoas explicitem suas dúvidas sobre a cirurgia, a fim de esclarecê-las. Os enfermeiros esperam que essas pessoas tenham dúvidas relacionadas a questões técnicas e, muitas vezes não se preocupam em dialogar a respeito de questões mais profundas como: dor, medo, mutilação, sexualidade e até morte. Mas, parece que muitos pacientes têm estes tipos de preocupações e gostariam de abordá-los com alguém.

Alguns trabalhos enfatizam as percepções e as expectativas que os pacientes têm do enfermeiro. Caldonha e Mendes ${ }^{17}$ encontraram $100 \%$ dos pacientes entrevistados afirmando que gostariam de uma 
abordagem pré-operatória pelo enfermeiro a fim de esclarecer dúvidas. Nestes mesmos entrevistados, $91,6 \%$ gostariam de conversar com o enfermeiro sobre algum tipo de medo no pré-operatório. Menezes ${ }^{36}$ citada acima, por sua vez, afirma que o que os pacientes mais esperam do enfermeiro é que haja diálogo, carinho, bons cuidados e permanência ao lado deles.

Assim, pode-se ressaltar a importância da verbalização por parte dos pacientes, de seus medos, fantasias, sentimentos e preocupações relacionados à cirurgia, com o intuito de diminuir a ansiedade.

De modo geral, a assistência de enfermagem ao paciente cirúrgico segue um processo denominado Sistematização da Assistência de Enfermagem Perioperatória (SAEP), que consiste em: histórico do paciente cirúrgico; diagnósticos de enfermagem; planejamento e metas; prescrições de enfermagem; evolução. Este processo compreende os três períodos cirúrgicos: pré, trans e pós-operatório e visa atender as necessidades do paciente cirúrgico e sua família.

A assistência pré-operatória inicia-se quando se estabelece a decisão para a intervenção cirúrgica e termina com a transferência do paciente para a mesa cirúrgica. $O$ âmbito das atividades de enfermagem pode começar antes da internação através de uma entrevista e realização de ensino preparatório, mas geralmente a assistência de enfermagem préoperatória irá iniciar com a visita pré-operatória ${ }^{59}$, que será abordada a seguir. 


\subsection{A visita pré-operatória}

A visita pré-operatória tem 0 intuito de promover a continuidade da assistência profissional iniciada no ambulatório e na unidade de internação. Ela normalmente é realizada pela enfermeira do centro cirúrgico.

A enfermeira nesta visita busca conhecer os pacientes, seus problemas, suas necessidades e dá oportunidade para que esclareçam as dúvidas específicas sobre o centro cirúrgico e tudo que envolve o período perioperatório. Esse período compreende a preparação do paciente para a cirurgia, o ato cirúrgico em si realizado no centro cirúrgico e o tratamento pós-cirúrgico desde a permanência na Unidade de Terapia intensiva até a alta hospitalar.

Para compreender quando surgiu e como era realizada a visita pré-operatória, foi realizada uma revisão bibliográfica nas bases de dados LILACS, MEDLINE, BDENF, MEDCARIBE e diretamente nas bibliotecas da Escola de Enfermagem da USP e BIREME. Pôde-se constatar que as divulgações de pesquisas feitas por enfermeiros que visitavam pacientes em momento anterior à cirurgia começaram a aparecer por volta dos anos 60, do século XX, principalmente nos Estados Unidos. Estas pesquisas ganharam ênfase na década de 70 , que representou um período bastante rico em artigos que indicavam a necessidade da visita préoperatória e a recomendavam.

A partir da década de 90 , a literatura norte-americana tornou-se mais voltada à necessidade do trabalho educativo da enfermagem como um todo. Encontrou-se menor quantidade de artigos específicos sobre o período pré-operatório desde esta data, possivelmente por ter havido uma conscientização e utilização deste procedimento como rotina. 
No Brasil, foi na década de 80 que ocorreu uma ênfase nas pesquisas sobre a educação pré-operatória, que era voltada, principalmente, para os aspectos relacionados à necessidade de orientação aos pacientes cirúrgicos, com o intuito de diminuir problemas pós-operatórios tanto físicos quanto emocionais, além do tempo de internação hospitalar.

Assim, foram encontradas inúmeras publicações em livros, artigos de periódicos e teses, em toda a literatura norte-americana e brasileira, que recomendam e reforçam a importância da visita préoperatória- ${ }^{5-20,26,31,32,36-38,52,60,61}$. Algumas delas também criticam a falta desta assistência em muitas instituições de saúde ${ }^{10,13,18,20,37,38,61}$.

Nessa revisão, verificou-se que a forma de realização da visita pré-operatória consiste basicamente em conhecer os pacientes cirúrgicos, coletar suas necessidades, oferecer informações e orientações sobre todo o período pré-operatório (atentando para aquilo que eles realmente querem saber) e esclarecer dúvidas.

Bianchi e Castellanos ${ }^{8}$ fizeram uma revisão bibliográfica da literatura estrangeira sobre a visita pré-operatória da enfermeira de centro cirúrgico e destacaram alguns métodos para a realização da visita préoperatória. O primeiro deles consistia na Técnica da Entrevista. Para tal procedimento era feita uma consulta ao prontuário médico e colhidas informações do paciente fornecidas pela enfermagem da unidade de internação. Com esses dados, abordava-se, então, o paciente, explicandoIhe os objetivos da visita. Buscava-se, nessa abordagem, criar um clima favorável ao diálogo, que possibilitasse a ele expressar suas dúvidas.

No segundo método denominado de Visita Estruturada, quando a enfermeira após colher os dados do paciente apresentava-se a ele e procurava esclarecê-lo sobre todo o preparo necessário à cirurgia, além de como seriam realizados os procedimentos no centro cirúrgico e na recuperação pós-operatória. 
O terceiro método denominado Técnica Rogeriana consistia em, primeiramente, deixar o paciente falar tudo o que quisesse para depois orientá-lo sobre: preparo pré-operatório; anestesia; informações à família; maneira de reagir à cirurgia; tipo e natureza dos equipamentos usados; natureza geral da dor que é esperada; exercícios para respiração profunda na sala de recuperação pós-anestésica e local da incisão. Além disso, enfocava a necessidade de deambulação precoce, medicamentos e tratamentos especiais no pós-operatório e dia esperado para alta hospitalar.

O último método mencionado na revisão da literatura feita por Bianchi e Castellanos ${ }^{8}$, era o do Ensino em Grupo, que consistia em fornecer orientações sobre todo o procedimento cirúrgico e recuperação pósoperatória, muitas vezes utilizando recursos áudio-visuais para mostrar os ambientes pelos quais os pacientes iriam passar.

O primeiro método, da Técnica da Entrevista, é o mais mencionado nas pesquisas nacionais publicadas na década de 80 e 90, do século passado ${ }^{12,14,52,60}$.

O último método, de Ensino em Grupo, é defendido por vários autores, pelo fato de reunir pacientes que estarão passando pela mesma experiência, podendo encontrar apoio um no outro ${ }^{5,6,9,62,63}$.

Apesar dessa defesa, da visita pré-operatória realizada em grupos, encontraram-se maior quantidade de estudos que faziam referência a essa abordagem na década de 70 . O primeiro deles foi exatamente em 1970, num hospital americano, quando Mezzanote $^{5}$ começou a fazer orientações pré-operatórias em grupo com o intuito de poupar tempo, e percebeu que estas reuniões possuíam um potencial terapêutico importante. Os componentes do grupo se apoiavam e ganhavam coragem ao se identificarem com outros na mesma situação. É mencionado por esse autor que as pessoas se sentiram menos sozinhas e que, quando perguntadas sobre suas preferências (orientações de forma individual ou grupal), a maioria preferiu as orientações pré-operatórias em grupo. 
Num estudo comparativo sobre os efeitos das orientações individuais e grupais no pós-operatório, Lindeman ${ }^{62}$ em 1972, concluiu que as grupais foram mais eficientes que as individuais em relação à função pulmonar e exercícios respiratórios, no tempo de hospitalização, na necessidade de analgesia do pós- operatório e também no aprendizado.

Schmitt e Wooldrige ${ }^{6}$, em 1973, demonstraram poder melhorar as condições emocionais de pacientes cirúrgicos com uma reunião grupal no dia anterior à cirurgia, quando estes discutiam seus medos e preocupações e ainda recebiam informações sobre como ajudar no pósoperatório. Estas pessoas tornavam-se menos tensas e ansiosas, mais confiantes, com melhores condições de sono, utilizando menos drogas anestésicas e analgésicas, apresentando menor retenção urinária e ficando independentes mais rapidamente.

Depois da década de 70 , as pesquisas abordando pacientes em grupo parecem ter sido abandonadas, ou pelo menos não foram publicadas. De qualquer forma, ficou evidente que os estudos passaram a enfocar apenas as abordagens individuais. Talvez isto tenha ocorrido porque, desta forma pode-se preservar a individualidade dos pacientes, ou também, pelo fato do tempo de hospitalização ter diminuído nos últimos anos, dificultando a reunião grupal.

No Brasil, o trabalho de Kuhn, Kruse, Ruschel e Dovera ${ }^{9}$, em 1986, alcançou bons resultados com reuniões grupais de pacientes de pré e pós-operatório de cirurgia cardíaca, internados ou não, com uma equipe multidisciplinar composta por enfermeiros, fisioterapeutas, psicólogos, cardiologistas e anestesistas. Estas reuniões tinham como intuito principal, proporcionar aos pacientes a oportunidade de verbalizarem suas ansiedades e necessidades, deixando-se que uns esclarecessem as dúvidas dos outros, sendo que a interferência profissional ocorria quando eram identificadas necessidades de intervenção. Estes pacientes relataram satisfação com as reuniões e sentiram-se mais encorajados para enfrentar o procedimento cirúrgico. 
Estes trabalhos que mostraram as orientações préoperatórias feitas em grupos pareceram bastante interessantes, especialmente por evidenciar que na abordagem profissional eram considerados os sentimentos e as preocupações emocionais dos pacientes que se encontravam em pré-operatório, além de promover maior interação e trocas com outras pessoas que vivenciavam situações semelhantes. Além desses aspectos, deve-se destacar que a abordagem em grupo possivelmente levaria à economia de tempo do profissional que daria orientações pré-operatórias gerais, que não necessitariam ser repetidas para cada pessoa.

É importante destacar que os principais motivos para a não realização da visita pré-operatória pelos enfermeiros de centro cirúrgico, expressos na literatura, dizem respeito à sobrecarga de trabalhos burocráticos e à falta de profissionais em número suficiente para tal realização.

Nesse sentido, acredita-se que esses mesmos motivos abordados desde a década de 70 são perfeitamente atuais e rediscutidos nesta primeira década, do século XXI.

De qualquer forma, é de consenso na literatura, que a visita pré-operatória feita de forma individual ou grupal, é necessária e deve promover o ensino de pessoas no período pré-cirúrgico, através de orientações, pois isto poderá influenciar as fases posteriores da cirurgia, podendo reduzir as ansiedades e consequentemente as complicações pósoperatórias e o tempo de internação hospitalar ${ }^{12,14,16,19,26,60}$. 


\section{OBJETIVOS}

- Identificar os níveis de ansiedade e de medo nas pessoas que iriam se submeter à cirurgia de revascularização do miocárdio (RM).

- Implementar uma estratégia de orientação grupal na visita pré-operatória, na abordagem psicossocial, para as pessoas que apresentaram medo e ansiedade no préoperatório de cirurgia de RM.

- Comparar os níveis de ansiedade e de medo entre as pessoas que receberam as orientações tradicionais da instituição e aquelas que participaram da estratégia de orientação grupal na visita pré-operatória.

- Apreender o significado das orientações pré-operatórias segundo a percepção das pessoas participantes dos grupos. 


\subsection{Referencial teórico}

A história da psicologia começa com o estudo do indivíduo e seus processos emocionais pessoais independentemente de influências do meio em que ele sobrevive, como se só os processos psicológicos internos fossem as causas para explicar seus comportamentos. Posteriormente começaram a aparecer estudos que levaram em conta o fato do ser humano não ser apenas biológico, mas também social. Assim sendo, surgiu a psicologia social com o intuito de recuperar o indivíduo na intersecção de sua história e a história de sua sociedade. Com ela aprendemos a entender as determinações sociais e culturais de seu comportamento e a enxergar o homem como produto e produtor de sua história pessoal e social. Com a psicologia social percebemos que o homem não sobrevive senão em relação com outros homens, ou seja, em grupos. As pesquisas nesta área se definem por relações sociais entre pesquisador e pesquisado que podem ser reprodutoras ou transformadoras das condições sociais onde ambos se inserem. Assim, não há possibilidade de se gerar um conhecimento "neutro". O conhecimento do outro sempre vai interferir na existência daquele que está conhecendo. Desta forma, sempre a pesquisa implica intervenção ou ação de uns sobre outros, mesmo que a ação não seja consciente. Para Lane $^{64}$, pode-se "dizer que o homem ao falar transforma o outro e, por sua vez, é transformado pelas conseqüências de sua fala" ${ }^{\text {" }}$.

Embora não se trate de um estudo que tem a psicologia social como referencial teórico, essas considerações são aspectos importantes para configurar a pessoa cuja singularidade se expressa também pelo intercâmbio com as singularidades de outros sujeitos e com o seu entorno e se constitui, assim, como ser psicossocial. 
Nesse sentido, o cuidado do indivíduo na perspectiva psicossocial se baseia em alguns princípios construídos por $\operatorname{lde}^{65} \mathrm{e}$ Püschel $^{54}$ que são pautados:

- pela percepção de que as experiências vivenciadas pelo indivíduo produzem uma ampla teia de significados que o indivíduo constrói no intercâmbio social, ${ }^{66}$

- pela valorização de conteúdos mentais de natureza subjetiva e social como sistemas representacionais de ser e estar no mundo mediados pela linguagem, ${ }^{67}$

- pelo investimento na personalização do atendimento, promovendo o desenrolar temporal do prognóstico, relacionando-a a estrutura do sujeito, sua história, seus lutos, seus afetos e seus momentos de desorganização, ${ }^{65}$

- pela tentativa de superar o caráter doutrinário dos processos educativos em saúde. Quando as palavras são usadas para impor ou lutar com o indivíduo cuidado, sem compartilhar o conteúdo, ocorre a doutrinação. Essa é perigosa por nascer uma deturpação da compreensão e não do conhecimento; ${ }^{68}$

- pela compreensão de "que a experiência do adoecer envolve o entendimento do processo de produção do conhecimento e dos idiomas e narrativas mediante as quais tal conhecimento é apresentado e assimilado, as representações lingüísticas que devem ser compartilhadas pelo maior número possível de pessoas envolvidas na questão". 69

De acordo com estes princípios, considera-se que a atuação do profissional deve se basear nas necessidades, nas expectativas e nas 
possibilidades de cada pessoa, oferecendo a ela a oportunidade para o agir expressivo e para o enfrentamento das situações.

Este estudo se baseia neste referencial ao se buscar aplicar uma estratégia de intervenção grupal, na abordagem psicossocial. Esta abordagem considera a pessoa na sua multidimensionalidade, utilizando-se da relação empática e do estabelecimento de vínculo como ferramentas ${ }^{54}$. Falcone ${ }^{70}$ se refere ao ouvir sensível e empático, que significa dar ao outro a oportunidade de se expressar em seus próprios termos sem ser julgado. Desta forma, a pessoa se sente não só entendida, como também aceita e valorizada. Isto promove auto-aceitação e auto-afirmação, provoca efeitos positivos, tanto para o que ouve quanto para a outra pessoa.

A empatia envolve elementos cognitivos e afetivos e é definida como "habilidade cognitivo-afetiva de integração, agregando a capacidade de discriminar chaves afetivas no outro, assumir a perspectiva do outro (sempre na condição de outro), respondendo afetivamente ao seu sofrimento, transmitindo entendimento de tal maneira que este se sinta verdadeiramente compreendido e acolhido. (...) A forma mais elaborada de empatizar promove: maior entendimento na interação, intensificação do afeto, alívio da angústia da outra pessoa (com possíveis mudanças na condução dos seus problemas), tornando o empatizador mais aceito e com auto-estima elevada"70. Falcone ${ }^{70}$ cita as etapas do processo empático definidas por Rogers: "1. captar e familiarizar-se com o mundo perceptual da outra pessoa, sem julgá-la; 2. comunicar ao outro a própria percepção do mundo deste, observando elementos que o outro teme; 3. verificar com o outro a correção de tais percepções e deixar-se guiar pelas respostas deste".

Acredita-se que a estratégia proposta permite uma maior aproximação entre a enfermeira e os participantes da pesquisa, com maior possibilidade de trocas interativas e, portanto, contribui para reduzir ansiedades e medos. 
Sendo assim, a abordagem psicossocial surge, então, como proposta complementar, que possibilita à pessoa que se submeterá à cirurgia de RM, condições para verbalizar os seus sentimentos e ouvir outras pessoas que passarão pela mesma situação. O papel da enfermeira consiste em dar orientações pertinentes às necessidades dos sujeitos envolvidos sob a perspectiva deles, utilizando-se a escuta sensível como ferramenta.

A opção pela abordagem em grupo se ampara no fato de que a experiência grupal pode desencadear insight $e$ promover a transformação de si mesmo e do outro.

Existem muitas teorias para explicar o trabalho com grupos. A maioria delas bastante complexas e ligadas à psicoterapia. Não foi proposta deste estudo o aprofundamento na discussão sobre estas teorias, mesmo porque não houve interesse no prolongamento dos encontros grupais, tendo sido estes resumidos a um encontro apenas com limite de horário. De qualquer forma houve o objetivo de se alcançar um benefício terapêutico para diminuir a ansiedade e o medo dos participantes do grupo.

Portanto, como interesse para a presente pesquisa encontrou-se um autor que tenta compreender alguns caminhos naturais pelos quais os grupos estabelecem relações que norteiam sua efetividade terapêutica. Pretende-se assim citar alguns fatores facilitadores do funcionamento grupal propostos por Yalom*, que explicam as vivências grupais.

Instilação de esperança: no relacionamento grupal são estabelecidas algumas trocas onde as experiências similares induzem discussões e compartilhamento de vivências, facilitando a percepção de que as coisas podem ser diferentes.

Universalidade: o ser humano costuma acreditar que seus problemas são únicos, o que pode trazer uma sensação de solidão. Quando

\footnotetext{
* Yalom ID. The theory and practice of group psychotherapy. 4 ed. New York: Basic Books;
} 1995. 
colocados em situação grupal descobrem que seus problemas são compartilhados por outros, ou seja, são "universais". Esta experiência traz alívio aos participantes.

Oferecimento de informações: ocorre quando o coordenador oferece instruções didáticas ou orientações acerca de problemas.

Altruísmo: ao compartilharem problemas similares os participantes oferecem apoio e sugestões uns aos outros, sentindo-se úteis. Esta experiência é gratificante e aumenta a auto-estima, além de desviar a atenção de acontecimentos que despertam ameaças psicológicas.

Comportamento imitativo: utilizar as atitudes e comportamentos de demais integrantes inclusive do coordenador como espelho. É um recurso próprio do ser humano.

Catarse: é um aspecto da experiência grupal que permite a expressão de sentimentos de reconhecido valor terapêutico. Liberação de emoções ou tensões reprimidas.

Coesão do grupo: atração que os participantes sentem entre si e pelo próprio grupo, fazendo com que haja aceitação mútua, oferecimento de apoio e formação de vínculos.

O coordenador deve ter alguns cuidados ao planejar um grupo. Deve haver uma preparação dos integrantes com termos claros concretos e incentivadores. Desta forma, pode-se conseguir um clima de confiança e segurança a fim de alcançar os objetivos a que a reunião se propõe.

Medeiros $^{28}$, em 2002, sugeriu que uma das estratégias eficientes para diminuir a ansiedade de pacientes em período pré-operatório poderia ser a de compartilhar as emoções com outros pacientes, buscando ou trocando informações. Sendo assim, a estratégia de orientação grupal possibilitou alcançar essa finalidade. 


\subsection{Referencial metodológico}

\subsubsection{Tipo de estudo}

Trata-se de um estudo de natureza quantitativa e qualitativa.

$\mathrm{Na}$ abordagem quantitativa, foi realizado um ensaio clínico controlado randomizado. Para Fletcher ${ }^{71}$, este tipo de estudo se configura "como padrão de excelência para estudos científicos sobre o efeito do tratamento. Chama-se de tratamento qualquer intervenção que pretende melhorar o curso da doença, uma vez que ela esteja estabelecida. Isto inclui as prescrições médicas, procedimentos cirúrgicos, aconselhamentos e até terapia de relaxamento".

Nesta pesquisa, a intervenção utilizada visava contribuir para a redução dos níveis de ansiedade e de medo das pessoas que se submeteriam à cirurgia de revascularização do miocárdio.

Para analisar os efeitos de uma intervenção clínica, a melhor forma que se pode utilizar para a escolha dos sujeitos e designá-los para cada grupo é a alocação aleatória ou randomização. Somente desta forma podem ser gerados grupos verdadeiramente comparáveis. $O$ tratamento deve ser determinado pela randomização e não pela escolha do interventor ou do paciente ${ }^{71}$.

O grupo exposto à intervenção é chamado de experimental, enquanto que o outro é denominado grupo controle.

Neste estudo, chamou-se de grupo experimental ou de intervenção aquele que recebeu as orientações de forma grupal na abordagem psicossocial. O grupo controle foi constituído por pessoas que 
receberam orientações da forma tradicional feita pela instituição pesquisada. Pôde-se, desta forma, proceder à comparação entre os grupos.

A abordagem qualitativa visou apreender o significado das orientações pré-operatórias, segundo a percepção das pessoas participantes do grupo de intervenção.

Segundo Minayo ${ }^{72}$, as metodologias de pesquisa qualitativa são "aquelas capazes de incorporar a questão do significado e da intencionalidade como inerentes aos atos, às relações e às estruturas sociais, sendo essas últimas tomadas tanto no seu advento quanto na sua transformação, como construções humanas significativas".

A pesquisa participante deve ser um processo construído pelo pesquisador juntamente com as pessoas envolvidas. Para isso, Minayo $^{72}$ afirma que o pesquisador deve ter uma atitude de observador científico, que consiste em colocar-se sob o ponto de vista do grupo pesquisado, com respeito e empatia, tornando a inserção o mais íntima possível. Isto significa que a interação social faz parte da condição e da situação de pesquisa. 


\subsubsection{Local do Estudo}

Esta pesquisa foi realizada em um hospital especializado em cardiologia localizado no município de São Paulo. O centro cirúrgico deste hospital possui quatro salas operatórias, que realiza em média sete cirurgias diariamente, totalizando uma média mensal de 140 cirurgias.

Em 2005, foram realizadas 1.740 intervenções cirúrgicas. Destas, 717 foram cirurgias de revascularização do miocárdio (41\%), 474 procedimentos para correções de valvas cardíacas (27\%), 287 cirurgias para correções de problemas congênitos (16\%) e ainda, 262 intervenções diversificadas, entre transplantes cardíacos e renais, aneurismas de aorta torácica e abdominal, drenagens, revisões de hemostasia, entre outras (16\%).

Esta instituição atende principalmente pacientes do Sistema Único de Saúde (SUS), mas também alguns conveniados.

O quadro de enfermeiras, que atua nos períodos da manhã e tarde, é constituído por uma enfermeira diretora, duas assistenciais e uma enfermeira chefe da central de materiais. Este setor responde pela esterilização não só de materiais para as cirurgias, mas também para todas as outras unidades, o que faz com que a enfermeira da central de materiais fique ocupada apenas com esta tarefa.

O papel das enfermeiras consiste em fazer a previsão e provisão de materiais cirúrgicos, atividades de planejamento, organização e supervisão das atividades realizadas nas salas cirúrgicas. A enfermeira assistencial do período da manhã ocupa uma parte do tempo com a visita pré-operatória grupal e recepção dos pacientes no centro cirúrgico. As enfermeiras fazem também a evolução trans-operatória utilizando os diagnósticos de enfermagem, conforme impresso próprio. 
Na instituição estudada, foi implantada a SAEP em 1990, a partir de um estudo feito com 627 pacientes cirúrgicos, visitados por uma enfermeira do centro cirúrgico nos períodos de pré e pós-operatório ${ }^{15}$. A partir de então, uma enfermeira do centro cirúrgico ficava encarregada de realizar a visita pré-operatória. Além de colher os dados necessários ao recebimento do paciente no centro cirúrgico, ela oferecia orientações sobre: jejum, tricotomia, retirada de próteses e adornos, possibilidade de suspensão da cirurgia, ambiente do centro cirúrgico, entrada na sala de operações, anestesia, intubação, possíveis alergias, fases da cirurgia, recuperação pós-operatória na unidade de terapia intensiva e dor.

Além disso, havia uma preocupação em identificar possíveis problemas ou apreensões ligadas ao tratamento e resolução de dúvidas. Os familiares também eram orientados a respeito dos horários para informações, visitas e doação de sangue.

Houve, porém, no final da década de 1990, uma diminuição no número de enfermeiras na unidade de centro cirúrgico, fazendo com que houvesse o acúmulo de funções e o aumento das atividades burocráticas, 0 que provocou o afastamento, em muitos momentos, do atendimento direto aos pacientes, na visita pré-operatória.

Tal problema tem sido citado na literatura, uma vez que se tornou comum em muitas instituições de saúde $8,12,13,18,61$.

$\mathrm{Na}$ instituição a visita pré-operatória é realizada de forma grupal, visando economia de tempo da enfermeira. As orientações são feitas abordando os mesmos assuntos da visita individual (enfoque técnico) e a enfermeira se coloca à disposição para solucionar dúvidas. Ainda assim, esta visita fica prejudicada toda vez que a enfermeira fica sobrecarregada com outras tarefas burocráticas, o que ocorreu durante a coleta de dados para esta pesquisa em função da mudança do centro cirúrgico. 


\subsubsection{Sujeitos do estudo}

Os sujeitos deste estudo foram constituídos por pessoas da faixa etária entre 55 e 70 anos, internados para se submeter à cirurgia de revascularização do miocárdio ( $\mathrm{RM})$, realizadas de forma eletiva; que estavam aptos a se comunicarem; que concordaram em participar da pesquisa e que participaram efetivamente de todas as etapas da pesquisa descritas a seguir. Estes constituíram os critérios de inclusão.

Esta faixa etária foi escolhida por representar o grupo de maior porcentagem neste tipo de cirurgia na instituição, o que se pressupõe formar um grupo relativamente homogêneo.

A escolha de pessoas que se submeteriam à RM justifica-se por possuírem a mesma patologia de base e representar o tipo de cirurgia cardíaca mais comum realizada nesta instituição.

Para ser incluído, o indivíduo deveria relatar no primeiro contato com a pesquisadora algum nível de medo e/ou ansiedade, conforme escala específica (Anexo 1).

Foram excluídos os pacientes que já tinham sido submetidos à cirurgia de RM anteriormente e aqueles que estiveram impossibilitados de se reunir com o grupo de intervenção por motivos variados como: terapia intravenosa em bomba de infusão com drogas vasoativas e realização de exames fora do setor de internação no mesmo horário da intervenção.

Também foram excluídos aqueles sujeitos que ao serem abordados pela primeira vez referiram inexistência de medo e/ou ansiedade.

Sendo assim, o número total de participantes da pesquisa foi composto por 60 pessoas, sendo 30 no grupo de intervenção e 30 no grupo controle, conforme orientação de um estatístico. 


\subsubsection{Procedimento de coleta de dados}

A coleta de dados foi realizada de abril a setembro de 2006 e obedeceu às etapas explicitadas a seguir.

Primeira etapa - Foram identificados os pacientes em préoperatório para cirurgia de RM que atendessem aos critérios de inclusão. Primeiramente, a pesquisadora coletou no prontuário os dados individuais necessários para essa identificação. Em seguida, apresentou-se a cada um deles, explicando os objetivos da pesquisa e convidando-os a participar. Para aqueles que concordaram e assinaram o Termo de Consentimento Livre e Esclarecido (Anexo 2), foi aplicado um instrumento (Anexo 1) contendo dados de identificação (nome, idade, sexo, ocupação, escolaridade e registro hospitalar) e de avaliação do nível de ansiedade e de medo sentidos em relação à cirurgia. A escala utilizada foi uma escala tipo Likert, criada para esse fim, com notas de 1 a 6 que seriam atribuídas pelos participantes da pesquisa.

Na escala de ansiedade, o número 1 representava o nível de ansiedade inexistente; o 2, muito baixo; o 3, baixo; o 4, médio; o 5, alto e 0 6, muito alto.

Na escala de medo, o número 1 representava nível de medo inexistente; o 2, muito pequeno; o 3, pequeno; o 4, médio; o 5, grande e o 6 , muito grande.

Foi solicitado para cada paciente que atribuísse uma nota de 1 a 6 em relação ao seu nível de ansiedade e de medo, sendo que foram excluídos aqueles que atribuíssem nota 1 para o nível de ansiedade e de medo na primeira abordagem, pois este número significa ansiedade e/ou medo inexistentes de acordo com a tabela utilizada. Foram incluídos os pacientes que atribuíram uma nota mínima de 2 para ansiedade e/ou medo. 
Esta escala foi aplicada três vezes para cada participante da pesquisa, ou seja, nos períodos pré-operatório mediato, até doze horas antes da cirurgia, imediato (na chegada ao centro cirúrgico) e no pósoperatório, no máximo até o quarto dia.

Após a aplicação da escala, no período pré-operatório mediato foi entregue aos participantes o "manual de orientações de pré e pós-operatório" elaborado pelas enfermeiras do centro cirúrgico e utilizado para na visita tradicional da instituição.

Segunda etapa - Nesta etapa, foram definidos dois grupos de participantes.

O primeiro, denominado Grupo de Intervenção foi constituído por aqueles pacientes que apresentaram algum nível de ansiedade (2 a 6) e/ou de medo (2 a 6) e que concordaram em participar de uma reunião com a pesquisadora e outros pacientes, combinada para 0 mesmo dia, após o horário de visitas de familiares, que era realizado das 15 às 16 horas, conforme regra estabelecida pela instituição.

Os dados do grupo de intervenção foram colhidos às segundas e quartas-feiras. Tais dias foram escolhidos por apresentarem um maior número de internações em relação aos outros dias da semana. Houve assim, a possibilidade de compor um grupo de no mínimo quatro pessoas.

As reuniões foram realizadas num tempo médio de uma hora e trinta minutos.

Os participantes foram abordados de maneira grupal pela pesquisadora, para uma intervenção de reflexão e discussão sobre suas necessidades, suas ansiedades e seus medos.

A pesquisadora procurou esclarecer todas as dúvidas que foram surgindo durante a reunião incluindo as de origem técnica. 
O segundo, denominado Grupo Controle também foi constituído por aqueles pacientes que apresentaram algum nível de ansiedade (2 a 6) e/ou de medo (2 a 6). A diferença em relação ao primeiro grupo foi o fato de não ter havido qualquer tipo de intervenção por parte da pesquisadora. Os dados do grupo controle foram colhidos aleatoriamente em qualquer dia da semana, inclusive às segundas e quartas-feiras (desde que não houvesse número suficiente para constituir grupo de intervenção), pois não havia necessidade de abordá-los em grupo. Portanto, as pessoas deveriam apenas atender aos critérios de inclusão da pesquisa.

Terceira etapa - Todos os pacientes tanto do grupo de intervenção como do grupo controle foram abordados na maca, no momento em que estavam entrando no centro cirúrgico (pré-operatório imediato), para o segundo momento de avaliação do nível de ansiedade e de medo, conforme a escala descrita na primeira etapa (Anexo 1).

Quarta etapa - Esta última etapa ocorreu depois que os pacientes retornaram para as unidades de internação (enfermarias ou quartos), no $3^{0}$ ou $4^{0}$ dia de pós-operatório. Para as pessoas do grupo controle foi feita somente a aplicação da escala de avaliação da ansiedade e do medo. Para as pessoas do grupo de intervenção, além da aplicação da mesma escala, foi realizada também uma entrevista semi-estruturada para que eles respondessem às seguintes perguntas:

1. O que significou para o senhor(a) participar da atividade grupal de orientação pré-operatória com a enfermeira pesquisadora?

2. O que significou para o senhor(a) ter conversado com a enfermeira pesquisadora sobre sua ansiedade e seu medo?

3. O que o senhor(a) se lembra da orientação que recebeu no pré-operatório? 
4. O senhor(a) preferiria que as orientações fossem realizadas de forma individual ou grupal? 


\subsubsection{Método de abordagem do grupo de intervenção}

Identificando-se o nível de ansiedade e/ou medo nos participantes da pesquisa, o que se pretendeu com a estratégia de orientação grupal foi mobilizar nas pessoas suas emoções e trazer à tona suas expressões de ansiedade e medo em relação à cirurgia.

A intervenção grupal, por meio da abordagem psicossocial, visou proporcionar maior tranqüilidade às pessoas que se submeteram à cirurgia de RM, permitindo-Ihes verbalizar os seus sentimentos e ouvir outras pessoas que iriam passar pela mesma situação. O papel do enfermeiro consistiu em promover uma escuta sensível e dar orientações conforme as necessidades apresentadas pelos participantes dos grupos.

Para a abordagem do grupo, as pessoas foram reunidas em uma sala reservada no mesmo andar da unidade de internação. Não foi possível o isolamento total do grupo, pois havia a necessidade de medicar alguns pacientes durante o horário da intervenção.

Foram utilizadas algumas estratégias como jogos e dinâmicas que possibilitassem maior abertura para que estas pessoas expressassem seus sentimentos e suas necessidades de orientação de forma lúdica.

A opção pela utilização de jogos e dinâmicas foi que "o jogo nos desenvolve, na sua intensidade, uma fascinante energia que nos possibilita ir e vir, trocar e transformar, promovendo a descoberta, o encontro do homem consigo mesmo, com os outros e com o mundo cósmico"73. Reitera-se aqui, a afirmação de Oliveira e Rego ${ }^{74}$ de que "os seres humanos adultos, pertinentes a diferentes grupos culturais, têm os caminhos de seu desenvolvimento psicológico fortemente marcados por essa pertinência. Os processos cognitivos e afetivos, os modos de pensar e sentir, são 
carregados de conceitos, relações e práticas sociais que os constituem como fenômenos históricos e culturais".

A seguir são apresentadas as dinâmicas que foram utilizados na fase inicial da orientação grupal.

- Dinâmica de apresentação individual: os participantes sentaram-se em formato de roda, a fim de que todos pudessem ser vistos por todos. Em seguida foram convidados a contar a história do próprio nome (quem escolheu, qual o significado do nome, se gostava ou não do nome). Objetivo: resgatar a identidade, de forma lúdica, além de se fixar o nome da pessoa pela pesquisadora e pelos participantes do grupo.

- Dinâmica do papel: "O que eu sinto em relação à cirurgia é...". A pesquisadora pediu que registrassem num papel dois sentimentos negativos e um positivo que relacionados com a cirurgia. Objetivo: identificar os sentimentos relacionados ao processo cirúrgico.

- Dinâmica do mercado de troca: depois de registrarem os sentimentos, foi proposto que eles simulassem a participação em um "mercado". Eles deveriam "trocar suas mercadorias" (os sentimentos negativos e/ou positivos) com os outros participantes do grupo. Ao final, processaram como foi participar deste mercado, as facilidades e dificuldades encontradas para a troca das "mercadorias". Objetivo: promover a troca e a interação com os participantes.

Com a identificação dos sentimentos positivos e negativos registrados e trocados, a pesquisadora teve elementos para direcionar as suas orientações visando atender às necessidades do grupo. 
Para a finalização da atividade de orientação grupal foi utilizada uma dinâmica descrita a seguir.

- A Dinâmica do Barbante. Nesta dinâmica uma das pessoas do grupo pegava uma ponta do barbante e entregava o restante do rolo para uma outra pessoa qualquer do grupo (escolhida por ela), expressando o que sentia a respeito daquele momento, da atividade desenvolvida. Após todos terem jogado o barbante, a enfermeira processou o significado da rede que se formou e finalizou a atividade. Objetivo: avaliação da estratégia utilizada e do grupo. 


\subsubsection{Aspectos Éticos}

O projeto de pesquisa foi aprovado pelo Comitê de Ética em Pesquisa da Instituição onde foi realizada a pesquisa. (Anexo 3)

Os sujeitos da pesquisa do grupo de intervenção e do grupo controle foram convidados a participar do estudo e os que concordaram assinaram o termo de consentimento livre e esclarecido (Anexo 2). 


\subsubsection{Análise dos dados}

Os dados de caracterização dos grupos intervenção e controle foram analisados em números absolutos e percentuais.

Os níveis de ansiedade e de medo, assim como a comparação destes níveis entre os grupos (de intervenção e controle) foram submetidos à análise estatística.

Para a realização das análises estatísticas os dados foram armazenados e analisados com a utilização do programa estatístico Statistical Package for the Social Science (SPSS) versão 13.0.

No primeiro momento de avaliação dos sujeitos do estudo (baseline), os participantes dos grupos de intervenção e controle foram comparados em relação aos escores das variáveis de resultado da intervenção, com a utilização do teste $t$-student, após avaliar a aderência destas variáveis à distribuição normal.

As variáveis demográficas foram comparadas utilizando o teste qui-quadrado de Pearson, a fim de comparar a distribuição dos participantes segundo as categorias destas variáveis.

A avaliação da aderência à distribuição normal foi realizada através do teste de Kolmogorov-Smirnov. Constatou-se que os valores de $p$, maiores que 0,05 , indicaram que a variável tinha aderência norma ${ }^{75}$.

Para comparar os escores de ansiedade e de medo entre os grupos de intervenção e controle em cada um dos Momentos (1 ou primeiro, 2 ou segundo e 3 ou terceiro) foi utilizado o teste de $t$-student, a fim de avaliar se houve diferença estatisticamente significativa entre os dois grupos. Foi calculado ainda o effect-size (ES), para avaliar se também houve diferença clinicamente significativa. O ES tem sido adotado em vários 
estudos como indicador de diferença clinicamente significativa, sendo denominado de uma abordagem distribution-based para estimativa deste tipo de diferença ${ }^{76}$. O effect-size foi calculado considerando a fórmula apresentada abaixo, sendo que $X$ é o escore médio de ansiedade ou medo do grupos intervenção (G1) e controle (G2) dividido pelo desvio-padrão (pooled standard-deviation-S $S_{\text {pooled }}$ ).

O effect-size foi classificado considerando os pontos de corte estabelecidos por Cohen $^{77}$ :

- Pequeno $=0,2$ a 0,49

- Médio = 0,5 a 0,79

- $\operatorname{Largo}>\mathrm{ou}=0,8$

O efeito da intervenção nos níveis de ansiedade e de medo foi avaliado utilizando-se a análise de variância múltipla para medidas repetidas (MANOVA), acrescida do teste de múltiplas comparações de Bonferroni, visando identificar entre quais Momentos, M1, M2 e M3 houve diferença estatisticamente significativa ao longo do tempo.

Os resultados são considerados estatisticamente significantes quando $p$-valor $<0,05$.

As entrevistas semi-estruturadas relacionadas ao significado de ter participado da atividade grupal de orientação pré-operatória foram analisadas segundo a análise de conteúdo de $\operatorname{Bardin}^{78}$, cujo método é desenvolvido a partir de uma lógica de similaridade. Para Bardin ${ }^{78}$, a análise de conteúdo consiste "num conjunto de técnicas de análise das comunicações, visando obter por procedimentos sistemáticos e objetivos de descrição do conteúdo das mensagens, indicadores (quantitativos ou não) que permitam inferência de conhecimentos relativos às condições de produção e recepção (variáveis inferidas) destas mensagens". Na análise de conteúdo, leva-se em consideração as significações do conteúdo. O método 
consiste na organização da análise, constituída pela pré-análise, a exploração do material, tratamento dos resultados obtidos e interpretação.

Pré-análise - Nesta fase foi realizada a transcrição das entrevistas na íntegra e uma leitura inicial, para que houvesse uma familiarização com todo o material recolhido de forma global.

Exploração do material - Nesta fase foi feita uma leitura cuidadosa de cada entrevista, a fim de destacar expressões significativas da percepção dos participantes do grupo de orientações pré-operatórias. Estas expressões foram recortadas e agrupadas por semelhança de sentido, originando três categorias reagrupadas em subcategorias.

Tratamento e interpretação dos resultados - Nesta última fase foram realizados comentários, inferências e discussões sobre cada categoria e subcategoria construída. 
$\mathrm{Na}$ instituição estudada, a visita pré-operatória era realizada em grupos, por uma enfermeira do centro cirúrgico, com o intuito de otimizar o tempo. Esta enfermeira fazia orientações de acordo com as informações contidas no manual de orientações pré-operatórias e, em seguida, os distribuía aos pacientes como complemento.

Quando se iniciou a coleta de dados desta pesquisa, houve a mudança do centro cirúrgico e do setor de internação pré e pós-operatório, para um prédio recém-construído, a fim de ampliar o atendimento da instituição. Como este foi um momento de muitas mudanças e adaptações, o setor de enfermagem ficou sobrecarregado com atividades burocráticas. Sendo assim, durante toda a coleta de dados desta pesquisa não foi possível a realização da visita pré-operatória pela enfermeira do centro cirúrgico. Portanto, apenas as pessoas do grupo de intervenção receberam as orientações pré-operatórias que foram feitas pela enfermeira pesquisadora.

A idéia inicial é que todos os pacientes recebessem 0 mesmo manual de orientações pré-operatórias, tanto os do grupo de intervenção quanto os do grupo controle para que nenhum deles se sentisse prejudicado. Em função disso, o manual foi cedido pela instituição para a enfermeira pesquisadora em quantidade suficiente para distribuir a todos os participantes.

Foram abordadas 109 pessoas que se submeteriam à cirurgia de revascularização do miocárdio no período de 03 de abril a 28 de agosto de 2006. Destas, trinta e sete pessoas (33,9\%) referiram a inexistência dos sentimentos de ansiedade e medo, uma foi a óbito no pósoperatório imediato, oito permaneceram na Unidade de Terapia Intensiva além do quarto dia de pós-operatório (tempo limite estabelecido para a 
entrevista final) e três tiveram alta para serem operados posteriormente, por mudança de conduta médica. Sendo assim, 60 pessoas participaram efetivamente do estudo, sendo que 30 foram incluídas no grupo controle e trinta no grupo de intervenção.

Os resultados obtidos nesse estudo são apresentados da seguinte forma: caracterização dos sujeitos da pesquisa, descrição e análise das dinâmicas, níveis de ansiedade e de medo nos períodos pré-operatórios e pós-operatório e o significado da atividade de orientação pré-operatória no grupo de intervenção. 


\subsection{Caracterização dos sujeitos do estudo}

Os sujeitos participantes da pesquisa foram caracterizados segundo sexo, idade escolaridade e ocupação profissional conforme mostrado nas Tabelas 1 e 2 .

A Tabela 1 caracteriza os sujeitos deste estudo segundo sexo, idade e escolaridade nos grupos de intervenção e de controle. 
Tabela 1 - Distribuição dos sujeitos da pesquisa do grupo de intervenção e de controle, segundo sexo, escolaridade, estrato sócio-ocupacional e idade. Hospital especializado em cardiologia, São Paulo. 2006.

\begin{tabular}{|c|c|c|c|c|c|c|c|}
\hline \multirow[t]{2}{*}{ Características } & \multicolumn{2}{|c|}{ Amostra Total } & \multicolumn{2}{|c|}{ Intervenção } & \multicolumn{2}{|l|}{ Controle } & \multirow[t]{2}{*}{$\chi^{2}$ (p-valor) } \\
\hline & № & $\%$ & № & $\%$ & № & $\%$ & \\
\hline Sexo, $n(\%)$ & & & & & & & $0,32(0,57)$ \\
\hline Feminino & 18 & 30,00 & 10 & 33,33 & 8 & 26,67 & \\
\hline Masculino & 42 & 70,00 & 20 & 66,67 & 22 & 73,33 & \\
\hline Escolaridade, $n(\%)$ & & & & & & & $2,83(0,42)$ \\
\hline Analfabeto & 1 & 1,67 & 21 & 3,33 & 0 & 0,00 & \\
\hline Ensino Fund. Incomp. & 32 & 53,30 & 18 & 60,00 & 14 & 46,60 & \\
\hline Ensino Fund. Comp. & 7 & 11,60 & 3 & 10,00 & 4 & 13,30 & \\
\hline Ensino Médio Incomp. & 3 & 5,00 & 1 & 3,00 & 2 & 6,66 & \\
\hline Ensino Médio Comp. & 7 & 11,66 & 2 & 6,66 & 5 & 16,66 & \\
\hline Ensino Superior Incomp. & 1 & 1,66 & 0 & 0,00 & 1 & 3,00 & \\
\hline \multirow[t]{2}{*}{$\begin{array}{l}\text { Ensino Superior Comp. } \\
\text { Estrato sócio- }\end{array}$} & 9 & 15,00 & 5 & 16,66 & 4 & 13,33 & \\
\hline & & & & & & & $6,27(0,28)$ \\
\hline \multicolumn{8}{|l|}{ Ocupacional $n(\%)$} \\
\hline Alto & 7 & 11,67 & 3 & 10,00 & 4 & 13,33 & \\
\hline Baixo & 9 & 15,00 & 7 & 23,33 & 2 & 6,67 & \\
\hline Médio & 17 & 28,33 & 7 & 23,33 & 10 & 33,33 & \\
\hline Médio-alto & 8 & 13,33 & 4 & 13,33 & 4 & 13,33 & \\
\hline Médio-baixo & 8 & 13,33 & 2 & 6,67 & 6 & 20,00 & \\
\hline Sem ocupação & 11 & 18,33 & 7 & 23,33 & 4 & 13,33 & \\
\hline Idade & $62,02(4,08)$ & $55-70$ & $62,0(5,11)$ & $55-70$ & $62,03(4,57)$ & $55-70$ & \\
\hline
\end{tabular}

Conforme a Tabela 1 verifica-se que $70 \%$ dos participantes do estudo são do sexo masculino, tanto no grupo de intervenção (66,6\%), como no grupo controle $(73,3 \%)$.

Tal dado indica que a doença coronária continua atingindo mais homens que mulheres. Segundo dados de 2003 do Ministério da Saúde, Sistema Único de Saúde ${ }^{79}$ a taxa de mortalidade por doença isquêmica do coração é de 54,79 homens e 38,43 mulheres por 100.000 habitantes, o que demonstra que o grupo masculino lidera as estatísticas de morbi-mortalidade em relação ao feminino.

Há algumas décadas acreditava-se que a coronariopatia era uma doença tipicamente masculina, mas hoje se sabe que esta doença tornou-se a principal causa de morte no sexo feminino no mundo ocidental ${ }^{80}$. O que ocorre é que a coronariopatia se manifesta na mulher dez anos mais 
tarde que no homem. Esta diferença decorre da proteção hormonal do estrogênio na pré-menopausa. Este hormônio age diretamente no sistema vascular, inibindo a aterogênese e a trombogênese. Ele também diminui a captação de LDL pela parede arterial e possui atividade antioxidante e vasodilatadora $^{80}$. Desta forma a fisiologia feminina determina uma maior proteção até que comece a diminuição do estrogênio na fase da menopausa.

No que diz respeito à escolaridade de todos os participantes, verifica-se que a maioria $(53,3 \%)$ tem baixa escolaridade, ou seja, tem Ensino Fundamental incompleto, sendo que $60 \%$ são do grupo de intervenção e $46,6 \%$ do controle. Do total de indivíduos do estudo apenas um referiu não ter freqüentado escola em nenhum momento de sua vida. Do total, $15 \%$ das pessoas completaram o Ensino Superior, sendo que 5 delas $(16,6 \%)$ participaram dos grupos de intervenção e 4 (13,3\%) do grupo controle. De modo geral, cerca de um quarto das pessoas têm Ensino Médio completo ou Superior completo, o que indica que houve maior predominância de pessoas de baixa escolaridade participando do grupo de intervenção.

Os achados deste estudo em relação ao nível de escolaridade dos sujeitos parecem refletir a realidade brasileira, pois segundo dados do IBGE (Instituto Brasileiro de Geografia e Estatística) ${ }^{81}$, no ano de $2003,48,6 \%$ da população brasileira tinha o Ensino Fundamental incompleto e apenas 12,8\% completaram o Ensino Fundamental. Da população brasileira, apenas 16,3\% completaram o Ensino Médio e somente $6,4 \%$ concluíram o Ensino Superior. Além disso, 14,6\% da população não freqüentou escola.

Tal situação exigiu que a pesquisadora utilizasse linguagem mais simples para que houvesse compreensão por parte dessas pessoas acerca das orientações dadas tanto para o desenvolvimento das dinâmicas quanto para as orientações relacionadas ao pré-operatório. Deve-se destacar que várias pessoas necessitaram do auxílio da pesquisadora para escrever durante uma das etapas da intervenção. Expor-se em público pela 
falta de domínio da leitura e da escrita causou constrangimento em alguns participantes, o que foi contornado à medida que se desenvolveu o trabalho grupal. Porém, esta situação remete à necessidade da revisão da forma de realizar as orientações, especialmente pela utilização de estratégias que não dependam de leitura ou de escrita, para que se possa conseguir uma melhor participação e entrosamento.

Para realizar a distribuição dos participantes conforme estrato sócio-ocupacional dos grupos de intervenção e controle foi necessário categorizar as profissões a fim de possibilitar a análise estatística. Utilizou-se a classificação socioeconômica de ocupações proposta por Jannuzzi ${ }^{82}$. Este autor classificou as ocupações em cinco estratos sócio-ocupacionais que representam as ocupações típicas da população brasileira. Optou-se por esta classificação por ser construída a partir de uma combinação entre os dados de rendimento e escolaridade da população. Ele ainda organiza os estratos segundo "diferenças e similaridades das ocupações em relação ao caráter urbano/rural, manual/não-manual, aos setores de atividades e serviços, indústrias modernas e tradicionais -, nível de qualificação - técnicos, profissionais de nível superior -, nível de controle e autonomia - empregador, empregado e conta própria".

Fez-se necessário acrescentar a categoria sem ocupação, com o intuito de incluir os sujeitos que não se encontravam inseridos no mercado de trabalho, mas que participaram do estudo.

Pela Tabela 1, verifica-se que $18,3 \%$ de todos os participantes da pesquisa não estavam inseridos no mercado de trabalho, sendo que do grupo de intervenção correspondeu a 23,3\%. De modo geral, compõem essa categoria as mulheres que se dedicam a cuidar do próprio lar, sendo 7 (23,3\%) do grupo de intervenção e 4 (13,3\%) do grupo controle.

17 pessoas $(28,3 \%)$ de um total de 60 pertencem ao estrato sócio-ocupacional médio. As ocupações dessa categoria são constituídas 
por motorista, metalúrgico, granjeiro (proprietário), operador de máquina, oleiro (proprietário), topógrafo, reparador de aparelhos eletro-eletrônicos, representante de vendas, técnico em ótica e marceneiro. Deste total, 7 pessoas $(23,3 \%)$ participaram do grupo de intervenção e $10(33,3)$ do grupo de controle.

$25 \%$ dos participantes pertenciam ao estrato sócioocupacional médio-alto ou alto exercendo as atividades ocupacionais: bancário, pedagoga, advogado, comerciante, industrial, gerente técnico, jornalista, gerente comercial, publicitário, corretor de imóveis, professora e assistente social.

Observa-se também um número grande de pessoas ( 9 ou 15\%) na categoria de estrato sócio-ocupacional baixo, com 7 delas (23,3\%) tendo participado do grupo de intervenção e apenas $2(6,6 \%)$ participantes do grupo de controle.

Assim, $81,7 \%$ das pessoas que se submeteram à revascularização do miocárdio tinham uma ocupação e estavam, portanto, inseridas no mercado de trabalho. Além disso, $46,6 \%$ dos participantes do grupo de intervenção foram categorizados nos níveis médio, médio-alto e $53,2 \%$ nos demais níveis ou sem ocupação. Isso mostra que houve uma distribuição quase eqüitativa entre os dois níveis (médio para alto e médio para baixo/sem ocupação).

É interessante mencionar que as características sóciodemográficas não diferiram significativamente entre os grupos de intervenção e controle, indicando haver uma homogeneidade nos grupos.

Pode-se verificar também que de modo geral, todos os estratos sócio-ocupacionais estão utilizando o serviço público para realizar o tratamento para seu problema de saúde. Este fato mostra que na especialidade de cardiologia, existem hospitais públicos muito bem 
conceituados, de referência e que desenvolvem uma assistência de qualidade reconhecida.

A Tabela 1 também se refere à distribuição dos sujeitos por idade nos grupos (intervenção e controle). Optou-se por dividir a faixa etária total em três faixas menores, com intervalos de cinco anos nas duas primeiras faixas (55 a 59 anos e 60 a 64 anos) e na última de seis anos (65 a 70 anos).

Verifica-se que nos grupos de intervenção participaram dez indivíduos de cada faixa etária. No grupo controle houve a participação de onze sujeitos na faixa etária de 55 a 60 anos, nove entre os 60 e os 64 anos e dez entre os 65 e 70 anos, o que demonstra uma certa homogeneidade na distribuição da idade das pessoas que participaram, tanto do grupo de intervenção quanto do controle.

Laurenti $^{83}$, afirma que a incidência de afecções cardiovasculares em indivíduos a partir dos 40 anos tem apresentado aumento progressivo, embora pesquisas recentes indicam que a doença coronariana tem atingido indivíduos cada vez mais jovens.

$\mathrm{Na}$ instituição pesquisada, em levantamento realizado, verificou-se que a faixa etária mais atingida por esta doença ocorre dos 55 aos 70 anos. Não se pode desconsiderar também que há uma tendência de envelhecimento da população, o que contribui para o aumento das doenças crônico-degenerativas.

Sendo assim, é esperado aumento da incidência de doença coronariana nas pessoas mais jovens e nas mais idosas.

O processo vivenciado durante as intervenções grupais e a forma como se desenvolveram as dinâmicas são apresentados a seguir. 


\subsection{Descrição e análise das dinâmicas}

Foram realizados oito grupos de intervenção com as pessoas que se submeteriam à cirurgia cardíaca e que atendiam aos critérios de inclusão do estudo.

As dinâmicas foram introduzidas com 0 intuito de proporcionar um momento relaxante, possibilitando assim, que os participantes do grupo de intervenção expressassem seus sentimentos, dentro de um ambiente agradável.

Cada dinâmica utilizada nos grupos de intervenção é descrita abaixo.

\section{- Dinâmica de apresentação individual}

Os participantes entravam na sala de reunião sem se conhecerem e não imaginavam o que ia ocorrer, o que os deixava um pouco apreensivos, embora tivessem sido esclarecidos a respeito. A pesquisadora fazia a proposta desta primeira dinâmica e orientava que o objetivo era uma apresentação para que todos se conhecessem. A história dos nomes contribuiu para memorizá-los e possibilitou maior comunicação entre todos. Em alguns grupos houve a necessidade da pesquisadora indicar alguém para começar a falar, em outros, eles mesmos tomavam a iniciativa. Esta dinâmica facilitou o entrosamento do grupo, pois cada um teve a oportunidade de falar sobre si mesmo com seu nome e sua história.

Nem todos os participantes tinham uma história para contar a respeito do nome. Soube-se, posteriormente, que um dos participantes inventou uma estória divertida para seu nome, uma vez que não sabia contar uma história real, o que pareceu ser bastante positivo, pois demonstrou um querer ser incluído e estar presente na ação, no jogo. Outro discursou demoradamente sobre o sobrenome de sua família. Um terceiro ainda falou 
não só sobre a história de seu próprio nome, como também, como escolheu o nome de cada um de seus três filhos.

Assim, todos tiveram oportunidade de discursar a respeito de si mesmos, o que facilitou o início da reunião e a quebra de inibições, constrangimentos e, de certo modo, expectativas.

\section{- Dinâmica do papel}

No jogo do papel, foram distribuídos três pedaços de papel para cada participante e solicitou-se que cada um dos presentes escrevesse seus sentimentos em relação à cirurgia. Deveriam ser manifestados dois sentimentos negativos e um positivo, sendo que cada sentimento deveria ser escrito num papel separado.

Esta dinâmica ofereceu alguma resistência por parte dos integrantes dos grupos, pois muitos deles afirmavam não ter sentimentos negativos, desejando escrever apenas sentimentos positivos. Pediu-se então que apenas fossem sinceros e descrevessem seus três sentimentos. Mesmo assim, houve quem quis resumir tudo em uma única manifestação de sentimento. Outros ainda manifestaram os mesmos sentimentos com outras palavras.

Outro problema relacionado a esta dinâmica foi o fato de que alguns participantes não sabiam escrever, o que obrigou a pesquisadora a escrever para eles. Isto não resolveu totalmente o problema, pois eles também não sabiam ler o que estava escrito nos papéis, o que fazia parte do segundo momento da dinâmica. A pesquisadora solucionou este problema com o máximo de tranqüilidade e naturalidade para que estes participantes se sentissem aceitos no grupo e não sentissem constrangimento. Foi explicado a eles que esta estratégia era só uma forma de manifestação de sentimentos e que o importante era eles não deixarem de ser sinceros. Mesmo assim, alguns ainda ficaram um pouco constrangidos. 
No segundo momento a pesquisadora pediu então que eles expusessem seus sentimentos escritos. Os comentários surgiam naturalmente e abriam discursos bastante proveitosos, quando a pesquisadora interferia somente para esclarecer dúvidas ou fantasias e organizar as falas para que todos tivessem sua oportunidade. Alguns falavam o mínimo para cumprir a tarefa, mas a maioria se sentia estimulada para discutir os assuntos que surgiam e aproveitavam para fazer perguntas a respeito da cirurgia. Esta foi a parte da reunião onde os assuntos de natureza técnica foram esclarecidos a partir das dúvidas colocadas pelos próprios participantes. Estas dúvidas se relacionavam a detalhes técnicos da cirurgia e do pós-operatório.

Os sentimentos negativos que afloraram destas pessoas foram: medo de morrer, de deixar a família, de dor, do corte, da anestesia, do tubo orotraqueal, do resultado cirúrgico, de infecção hospitalar, de acidente cirúrgico, de ficar inválido, da cicatriz feia; preocupação; nervosismo; saudade da família; saudade de casa e insegurança com as novas orientações sobre alimentação e fumo.

Quanto aos sentimentos positivos, pode-se afirmar que quase a totalidade dos participantes citou a fé religiosa como sentimento positivo que os acompanha e fornece confiança e otimismo. Também foram citados os sentimentos de: confiança no médico; pensamento positivo; renascimento; renovação; vontade de viver mais; esperança; satisfação por estar numa instituição que confia e benção de Deus por ter descoberto a doença e poder tratar.

A partir da descrição e discussão destes sentimentos foi proposta a próxima dinâmica.

\section{- Dinâmica do mercado de trocas}

Esta foi uma dinâmica que não teve boa aceitação pelos participantes e precisaria ser revista. A maior parte dos participantes dos grupos não quis trocar seus sentimentos, mesmo que fossem negativos. 
Parece que estas pessoas se apegaram aos próprios sentimentos como se representassem suas próprias vidas e queriam vivenciar aquilo que realmente thes pertenciam. Uma delas chegou a afirmar que seus sentimentos positivos e negativos contrabalançavam, como se eles se organizassem de forma equilibrada e não permitissem a separação.

É importante considerar que essa dinâmica deveria ter sido apresentada anteriormente à discussão, comentários e síntese do grupo a respeito dos sentimentos que foram expressos.

\section{- Dinâmica do barbante}

Para encerrar a reunião grupal foi utilizada a dinâmica do barbante, quando cada participante deveria passar o barbante para qualquer outra pessoa presente e falar alguma coisa sobre aquele momento. Quando proposta, esta dinâmica deixava os participantes um pouco constrangidos por não saber bem o que dizer. O que os estimulou foi falar sobre seus desejos de bons presságios em relação ao processo cirúrgico. Alguns direcionavam seus desejos para a pessoa que recebia o barbante, enquanto outros desejavam de uma forma geral para todos os presentes. Outros ainda incluíam a pesquisadora, desejando que o estudo tivesse bons resultados e que ela também tivesse saúde e força para que as reuniões continuassem de forma definitiva na instituição e não só como uma pesquisa. Cada pessoa segurava uma parte do barbante e passava o restante do rolo para outra pessoa até que o rolo voltava para a mão de quem segurou a primeira ponta e uma figura se formava. Ao terminar a passagem do barbante por todos, enquanto eles ainda seguravam cada um a sua ponta, a pesquisadora chamava a atenção para conformação de um tipo de rede que ficava constituída pela figura formada pelo barbante. Como cada grupo passava 0 barbante em direções diferentes dos outros, as figuras formadas eram variadas. Apesar dessa variabilidade de figuras todas elas indicavam a formação de uma rede. 
Neste momento, a pesquisadora aproveitava a oportunidade para indicar a importância da rede como símbolo de união e interação entre eles, pois apesar de não se conhecerem bem, aquelas pessoas estavam dividindo uma experiência igualmente difícil para todos e poderiam usufruir daquele momento como apoio mútuo. Este tipo de finalização foi decorrente das falas dos participantes, pois ao serem convocados a falarem alguma coisa sobre aquele momento vivenciado, os discursos apareciam como desejo de que tudo desse certo para todos e que a fé religiosa os ajudasse a enfrentar aquele momento.

Em algumas das reuniões houve a necessidade da pesquisadora indicar a formação da rede, mas em outras, os próprios participantes percebiam e comentavam sobre a figura formada e a simbologia representada.

Alguns grupos passaram 0 barbante pela enfermeira pesquisadora, outros entenderam que só os pacientes deveriam participar. É importante ressaltar que eles tiveram total liberdade para fazer este tipo de escolha e que nada foi comentado a respeito, apenas observado.

Cabe salientar que durante este final de reunião a expressão das pessoas era de bem-estar. A pesquisadora aproveitava para realizar o fechamento da intervenção colocando-se à disposição dos participantes para o que precisassem durante a internação hospitalar.

Vale ressaltar que a posição da pesquisadora foi apenas de oferecer estímulo para que as pessoas falassem sem interferir nos assuntos escolhidos. Desta forma, algumas reuniões ficaram marcadas pela abordagem de aspecto mais técnico, enquanto que em outras foram mencionados mais os aspectos emocionais. Esta variabilidade ocorreu de acordo com o desejo manifestado pelos próprios participantes. A enfermeira pesquisadora limitou-se a oferecer os estímulos, esclarecer dúvidas e organizar os espaços para que todos pudessem se expressar. 


\subsection{Níveis de ansiedade e de medo nos períodos pré-operatório mediato, imediato e pós-operatório}

Os dados obtidos neste estudo foram submetidos à análise estatística e serão apresentados a seguir. Estes dados se referem aos níveis de ansiedade e de medo das pessoas que se submeteram à cirurgia de revascularização do miocárdio e, à comparação destes níveis entre aqueles que participaram da estratégia grupal de intervenção e os que apenas participaram do grupo de controle.

A comparação entre os grupos (intervenção e controle) foi realizada em três momentos. Chamou-se de momento 1 a avaliação de medo e ansiedade realizada no período pré-operatório mediato; momento 2 , o pré-operatório imediato e momento 3, o pós-operatório.

Os sujeitos incluídos neste estudo foram randomicamente e numericamente iguais na distribuição nos grupos experimental $(n=30)$ e controle $(n=30)$. Somente o grupo experimental foi submetido à intervenção, sendo então chamado de grupo de intervenção.

Tabela 2 - Média dos níveis de ansiedade e medo da amostra total e dos dois grupos (intervenção e controle) no primeiro momento (baseline). Hospital especializado em cardiologia. São Paulo, 2006.

\begin{tabular}{|c|c|c|c|c|c|c|c|}
\hline \multirow[b]{2}{*}{ Indicadores } & \multicolumn{2}{|c|}{ Amostra Total } & \multirow{2}{*}{$\begin{array}{l}\text { Intervenção } \\
\text { Média (dp) }\end{array}$} & \multicolumn{3}{|c|}{ Controle } & \multirow{2}{*}{$\begin{array}{r}\chi^{2} \text { (p-valor) } \\
0,27(0,98)\end{array}$} \\
\hline & $\begin{array}{c}\text { Média } \\
\text { (dp) }\end{array}$ & $\begin{array}{l}\text { Min- } \\
\text { Max }\end{array}$ & & Min-Max & $\begin{array}{l}\text { Média } \\
\text { (dp) }\end{array}$ & $\begin{array}{l}\text { Min- } \\
\text { Max }\end{array}$ & \\
\hline Ansiedade & $\begin{array}{c}4,05 \\
(0,87)\end{array}$ & $2-6$ & $4,03(0,93)$ & $2-6$ & $4,07(0,83)$ & $3-6$ & $0,15(0,88)$ \\
\hline Medo & $\begin{array}{c}3,55 \\
(1,42)\end{array}$ & $1-6$ & $3,27(1,64)$ & $1-6$ & $3,83(1,12)$ & $1-6$ & $1,56(0,12)$ \\
\hline
\end{tabular}

No primeiro momento de avaliação, os indivíduos de ambos os grupos apresentaram níveis médios de ansiedade e medo em relação à 
cirurgia. Não foram observadas diferenças estatisticamente significativas entre os dois grupos em relação às variáveis.

Em toda a literatura pesquisada sobre dados de avaliação de níveis de ansiedade medidos em momento anterior ao ato cirúrgico, foram encontrados apenas estudos que fazem referência à ansiedade média constatada na maior parte dos sujeitos de pesquisa. Embora exista muitas pesquisas sobre 0 assunto, optou-se por citar apenas a realizada por Peniche $^{84}$ realizada no ano de 2005, na mesma instituição utilizada para a realização deste estudo. Esta pesquisadora utilizou o questionário referente ao estado de ansiedade de Spielberger e encontrou como resultado uma porcentagem de $51,2 \%$ de pacientes com estado de ansiedade médio, o que ratifica os resultados encontrados nesta pesquisa.

Vale salientar que nesta abordagem, a primeira pergunta feita aos sujeitos era sobre o nível de ansiedade, sendo assim, a questão do medo era feita posteriormente. Quando a resposta era negativa, ou seja, o nível de ansiedade era inexistente, a enfermeira questionava também sobre o medo e este também era negativo em todos os indivíduos entrevistados. Assim, $100 \%$ dos sujeitos encontrados com sentimento de ansiedade inexistente afirmaram ter medo inexistente também. Mas, entre aqueles que possuíam algum nível de ansiedade e, portanto participaram da pesquisa, dez deles ou $17 \%$ referiram medo inexistente. 


\subsection{Efetividade da intervenção nas orientações grupais}

A efetividade da intervenção foi avaliada pelos escores de ansiedade e medo avaliados nos períodos pré-operatório mediato (momento 1), imediato (momento 2) e pós-operatório (momento 3). A hipótese levantada foi a de que os pacientes que participariam do grupo experimental (de intervenção) iriam referir menor nível de ansiedade e medo no momento 2 em relação aos pacientes do grupo controle.

Verificou-se que o maior nível de ansiedade e medo em ambos os grupos ocorreu no momento 1, seguido dos momentos 2 e 3 .

A hipótese inicial ficou confirmada quando se pôde observar que no momento 2 os pacientes do grupo de intervenção referiram menor nível de ansiedade e de medo que os do grupo controle. Esta diferença foi estatisticamente significativa, com o $\mathrm{p}=0,02$ para ansiedade e $\mathrm{p}=0,01$ para medo. Pode-se afirmar também que a diferença é clinicamente significativa observando-se o effect size, ES=0,65 para ansiedade e para medo. A Tabela 3 demonstra estes números. 
Tabela 3 - Comparação dos indicadores de resultados entre os grupos de intervenção e controle nos três momentos de avaliação. Hospital especializado em cardiologia, São Paulo, 2006.

\begin{tabular}{ccccc}
\hline Indicadores Experimental Controle t-student & $\begin{array}{c}p- \\
\text { valor }\end{array}$ & $\begin{array}{c}\text { Effect- } \\
\text { size }\end{array}$
\end{tabular}

Média DP Média DP

\section{Ansiedade}

$\begin{array}{lrrrrrrr}\text { M1 }{ }^{* *} & 4,03 & 0,93 & 4,07 & 0,83 & 0,15 & 0,88 & 0,05 \\ \text { M2 } & 2,90 & 1,42 & 3,83 & 1,46 & 2,50 & 0,02^{*} & 0,65 \\ \text { M3 } & 1,77 & 1,33 & 1,73 & 1,26 & -0,10 & 0,92 & 0,03\end{array}$

\section{Medo}

\begin{tabular}{rrrrrrrr} 
M1 & 3,27 & 1,64 & 3,83 & 1,12 & 1,57 & 0,12 & 0,04 \\
M2 & 2,53 & 1,74 & 3,63 & 1,63 & 2,53 & $0,01^{*}$ & 0,65 \\
M3 & 1,33 & 1,03 & 1,27 & 0,78 & $-0,28$ & 0,78 & 0,07 \\
\hline Diferença estatisticamente significante ao nivel de & $p<0,05 ;{ }^{* *}$ M=momento & & &
\end{tabular}

Para avaliar o efeito da intervenção sobre os escores de ansiedade e de medo e, ainda, estimar a mudança nos escores destas variáveis ao longo das três avaliações foi realizada a análise de medidas repetitivas (MANOVA) usando General linear modeling (GLM) independentemente nos grupos controle e intervenção. Na Figura 1 observase claramente que há uma redução nos escores entre o momento 1 e 2 .

Ao serem analisadas as mudanças ao longo do tempo em ambos os grupos foram observadas diferenças estatisticamente significativas no grupo controle (Traço de Hotteling=5,02; $p=0,00$ e Wilk's lambda=0,16; $\mathrm{p}=0,000$ ) e no grupo de intervenção (Traço de Hotteling=5,02; $\mathrm{p}=0,00$ e Wilk's lambda $=0,16 ; \mathrm{p}=0,000$ ). Entretanto, ao serem realizadas as últimas comparações entre os três momentos, nos dois grupos verificou-se que no grupo de intervenção, os escores de ansiedade nos três momentos foram estatisticamente diferentes entre si. Já no grupo controle houve diferença estatisticamente significativa apenas nos escores de ansiedade entre o segundo e terceiro momentos (Tabela 4). 
Tabela 4 - Comparação dos indicadores de resultados nas três avaliações nos grupos intervenção e controle. Hospital especializado em cardiologia, São Paulo, 2006.

\begin{tabular}{|c|c|c|c|c|c|c|c|c|c|c|c|}
\hline \multirow[t]{3}{*}{ Grupos } & \multicolumn{6}{|c|}{ Ansiedade } & \multirow{3}{*}{$\begin{array}{l}\text { Traço de } \\
\text { Hotelling }\end{array}$} & \multirow{3}{*}{$\begin{array}{c}\mathrm{p}- \\
\text { valor }\end{array}$} & \multirow{3}{*}{$\begin{array}{c}\text { Wilk's } \\
\text { lambd } \\
\text { a }\end{array}$} & \multirow[t]{3}{*}{ p-valor } & \multirow[t]{3}{*}{ Bonferroni, p-valor } \\
\hline & \multicolumn{2}{|c|}{ Momento 1} & \multicolumn{2}{|c|}{ Momento 2} & \multicolumn{2}{|c|}{ Momento 3} & & & & & \\
\hline & Média & DP & Média & DP & Média & $\mathrm{DP}$ & & & & & \\
\hline Intervenção & 4,03 & 0,93 & 2,90 & 1,42 & 1,77 & 1,33 & 3,188 & 0,000 & 0,239 & 0,000 & $\begin{array}{c}M 1>M 2, p=0,00 \\
M 2>M 3, p=0,002 \\
M 1>M 3, p=0,000 \\
M 1>M 3 \\
p=0,000 ; M 2>M 3 \\
p=0,000\end{array}$ \\
\hline \multirow{3}{*}{ Controle } & \multicolumn{6}{|c|}{ Medo } & Traço de & p- & Wilk's & p-valor & Bonferroni, p-valor \\
\hline & \multicolumn{2}{|c|}{ Momento 1} & \multicolumn{2}{|c|}{ Momento 2} & \multicolumn{2}{|c|}{ Momento 3} & Hotelling & valor & $\underset{a}{\operatorname{lambd}}$ & & \\
\hline & Média & $\overline{D P}$ & Média & $\overline{D P}$ & Média & $\mathrm{DP}$ & & & & & \\
\hline Intervenção & 3,27 & 1,64 & 2,53 & 1,74 & 1,33 & 1,03 & 3,188 & 0,000 & 0,239 & 0,000 & $\begin{array}{c}M 1>M 2, p=0,024 \\
M 2>M 3, p=0,003 \\
M 1>M 3, p=0,000 \\
M 1>M 3, p=0,000\end{array}$ \\
\hline Controle & 3,83 & 1,12 & 3,63 & 1,63 & 1,27 & 0,78 & 5,025 & 0,000 & 0,161 & 0,000 & $\mathrm{M} 2>\mathrm{M} 3, \mathrm{p}=0,000$ \\
\hline
\end{tabular}

Em relação aos escores de medo foram observados os mesmos resultados no grupo controle e no de intervenção. Diferença estatisticamente significante entre o primeiro e segundo momentos foi observada apenas no grupo de intervenção $(p=0,000$ para ansiedade e $\mathrm{p}=0,024$ para medo).

Assim, a mudança nos escores de ansiedade entre o primeiro e o segundo momentos foi clinicamente mais significativa no grupo de intervenção que no controle. A medida de effect-size do grupo de intervenção foi de 0,44 enquanto que no grupo controle foi de 0,14. 
Figura 1 - (A) Nível de ansiedade do grupo intervenção versus controle.

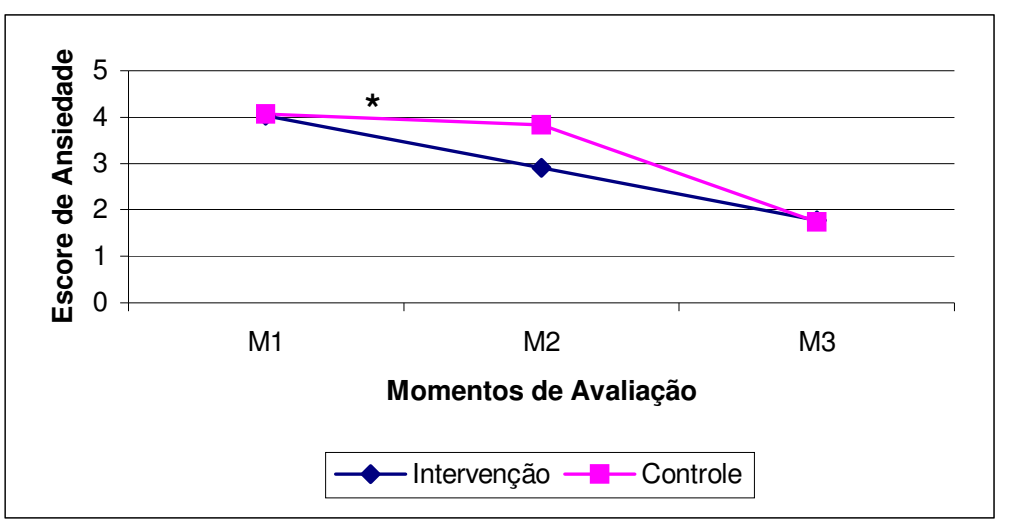

Figura 1 - (B) Nível de medo do grupo intervenção versus controle.

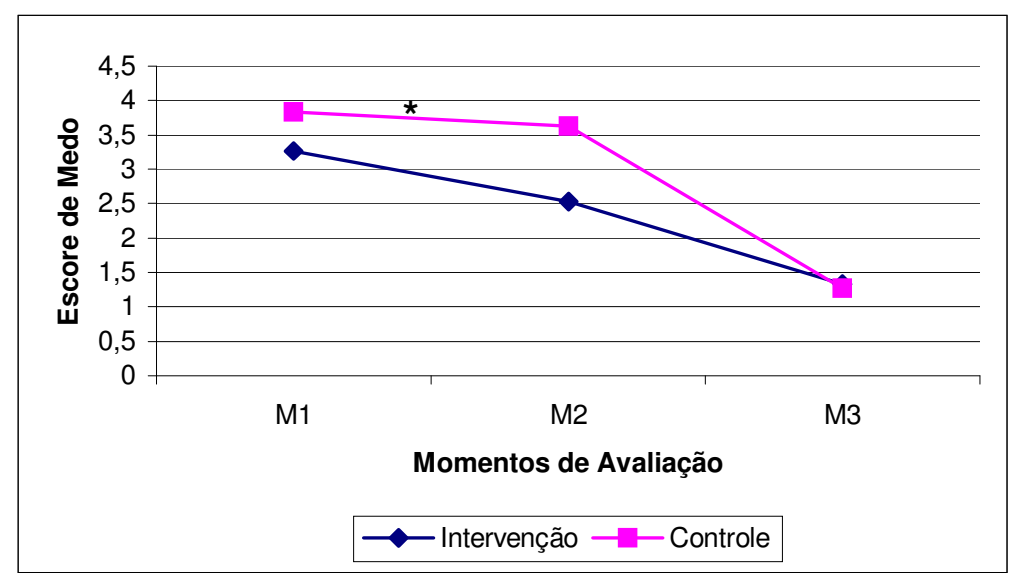

Julga-se importante comentar que no primeiro contato, tanto no grupo de intervenção quanto no de controle, ou seja, no momento 1 , a enfermeira pesquisadora além de entregar o manual de orientações para os sujeitos do estudo utilizou neste contato com a mesma postura afetiva, de abordagem psicossocial, que permeou toda a pesquisa. Acredita-se que 0 ouvir sensível e empático possibilitou aos indivíduos de se expressarem, sem serem julgados e sem pressa provocou efeitos positivos gerando confiança e possivelmente uma certa redução do medo e da ansiedade no pré-operatório imediato, mesmo nos indivíduos do grupo controle. 


\subsection{Limitações do estudo}

Um dos problemas que podem ocorrer ao interpretar resultados de ensaios clínicos é que algumas vezes a melhora de algumas condições é previsível. Ou seja, algumas condições ou situações têm como curso normal a melhora. Assim, o resultado efetivo da intervenção pode coincidir com a melhora e não causa-la ${ }^{71}$.

Os resultados deste estudo podem sugerir que a "melhora previsível" foi o que ocorreu entre o segundo e terceiro momentos, visto que tanto no grupo de intervenção quanto no de controle, observou-se diferenças estaticamente significantes nos escores de ansiedade e medo. Além disto, ao serem comparados os terceiros momentos do grupo de intervenção e controle não se observou diferença estatisticamente significante no escore de ansiedade $(p=0,92)$ e medo $(p=0,78)$. Entretanto, entre o primeiro e segundo momentos, a redução nos escores de ansiedade e medo observados no grupo de intervenção foram decorrentes da própria intervenção, visto que a diferença entre estes dois momentos foi estatística $(p=0,00$ e 0,008$)$ e clinicamente significantes (effect-size $=0,94)$.

Além disso, a redução nos escores de ansiedade e medo entre estes momentos no grupo controle não foi significativa $(p=0,015$ para ansiedade e $\mathrm{p}=0,014$ para medo); e os escores de ansiedade e medo do segundo momento diferiram significantemente entre ambos os grupos, sendo observados maiores escores nos controles no segundo momento que no grupo de intervenção ( $p=0,40$ para ansiedade e $p=0,44$ para medo). Cabe destacar que não foi observada diferença estatisticamente significativa entre grupo de intervenção e controle no primeiro momento $(p=0,88$ para ansiedade e $\mathrm{p}=0,12$ para medo).

Outro problema a ser abordado é o fato de os pacientes que são foco de interesse e atenção especial têm uma tendência natural a mudar o comportamento no sentido de querer agradar o pesquisador e ajudá-lo a 
conseguir bons resultados na pesquisa. Este efeito é denominado Hawthorne, segundo Fletcher, Fletcher ${ }^{71}$. Acredita-se que este não é o caso deste estudo, pois no momento 2, quando o paciente está na porta do centro cirúrgico, prestes a ser operado, a avaliação dos níveis de ansiedade e de medo nem sempre era feita pela enfermeira pesquisadora. Acredita-se que não deve ter havido interesse por parte dos participantes em agradar uma outra enfermeira que eles não reconheciam como pesquisadora. Assim o mais provável é que eles tenham sido sinceros. 


\title{
4.6 A vivência das dinâmicas utilizadas para a orientação pré- operatória no grupo de intervenção
}

\begin{abstract}
A partir da análise dos conteúdos apreendidos na avaliação dos participantes dos oito grupos de intervenção, pôde-se construir um esquema representacional da vivência das dinâmicas, apresentado na Figura 2. Nesse esquema verifica-se que as dinâmicas proporcionaram momentos lúdico e expressivo.
\end{abstract}


Figura 2 - Esquema representacional da vivência das dinâmicas

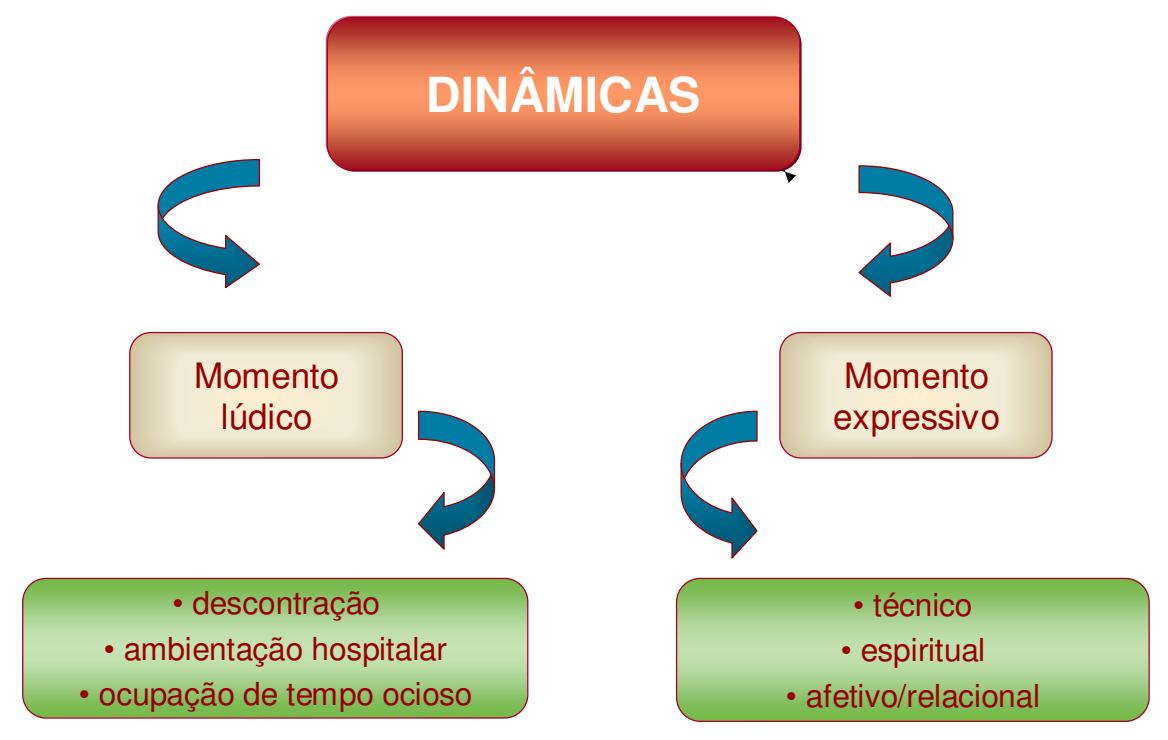

Como Momento lúdico, as dinâmicas possibilitaram a descontração, a ambientação hospitalar e a ocupação de tempo ocioso.

Com relação à Descontração na avaliação dos participantes, as dinâmicas foram entendidas como brincadeiras e atingiram o objetivo de descontrair o ambiente da reunião. Observou-se que a situação grupal permitiu mais facilmente a instalação de um ambiente descontraído que possivelmente não teria sido atingida se a abordagem fosse feita de forma individual. $O$ entrosamento e a troca de idéias também foram alcançados apesar das diferenças sócio-demográficas entre os participantes. Ao se colocarem como pessoas, mostrando um pouco de suas histórias particulares, elas deram o "primeiro passo" para o entrosamento grupal. No momento em que começaram a relatar seus sentimentos parece que o ambiente havia atingido a descontração suficiente para deixá-los à vontade, proporcionando a oportunidade de analisarem a si próprios e trazerem para a consciência seus sentimentos positivos e/ou negativos em relação ao ato 
cirúrgico. Ao final da reunião parecia haver uma sensação geral de animação para enfrentar o procedimento cirúrgico.

A Ambientação hospitalar foi conseguida uma vez que, a reunião grupal parece ter funcionado como uma sessão de entrosamento entre os participantes e o ambiente hospitalar. Foi como se alguém, no papel de porta-voz da instituição, reunisse aquelas pessoas para dar-lhes as boas vindas e deixá-los mais à vontade, para que a internação hospitalar não fosse tão penosa e eles pudessem interagir com outras pessoas que vivenciavam a mesma experiência de período pré-operatório de cirurgia cardíaca. Desta forma, puderam trocar muitas de suas expectativas pelo conhecimento do ambiente hospitalar. Quando eles saíam da sala de reunião era como se a instituição os tivesse acolhido efetivamente, ou seja, tivesse ocorrido um movimento de abertura para o acolhimento.

Por meio das dinâmicas utilizadas pôde-se promover a Ocupação de tempo ocioso. Este aspecto diz respeito à importância da ocupação de um tempo tradicionalmente ocioso da internação hospitalar com uma ação inesperada e marcante, que permaneceu reverberando em suas mentes por um tempo além daquele estritamente utilizado para a reunião grupal em si. Isto ficou claro quando na entrevista final os participantes comentaram que a reunião transformou-se em assunto tanto para os que participaram, como também para os que se internaram posteriormente.

Além do momento lúdico, as dinâmicas utilizadas para o grupo de intervenção possibilitaram também um Momento expressivo. Os sujeitos que participaram dos grupos de intervenção tiveram a chance de expressar suas dúvidas relacionadas aos aspectos técnicos, suas crenças espirituais e suas necessidades afetivas/relacionais.

No aspecto Técnico, a simples presença de uma pessoa que faz parte da equipe do centro cirúrgico estimula a resolução de dúvidas técnicas. É interessante observar que as pessoas muitas vezes não fazem 
todas as perguntas para o médico. A presença da enfermeira parece deixálos mais à vontade, pois eles tentavam esclarecer assuntos iniciados pelos médicos, mas não elucidados, segundo suas próprias falas. Uma das perguntas colocadas para a pesquisadora foi a respeito da "lesão de tronco" que o participante possuía, pois o médico havia comentado que o caso dele tinha este agravante. $O$ indivíduo que formulou esta questão tinha uma baixa escolaridade, porém não se esqueceu do termo utilizado pelo médico que o atendeu e viu na pesquisadora uma oportunidade de esclarecimento. A resolução das dúvidas parece fortalecer a confiança na equipe cirúrgica.

A expressão da crença Espiritual permeou o pensamento de todos os sujeitos participantes deste estudo, tanto de forma direta quanto indireta, como eles próprios citaram em suas falas. Eles tiveram oportunidade de discursar sobre suas crenças espirituais, independente do tipo de religião escolhida por cada um ou de suas condições intelectuais mais ou menos sofisticadas a respeito do assunto. Observou-se que o sentimento religioso sobrepujava todos os outros e assim, sempre que um sentimento negativo surgia no discurso, a fé religiosa era lembrada a fim de amenizar este sentimento desagradável. Eles desejavam que a proteção divina os acompanhasse durante o processo cirúrgico e alguns referiram ter certeza absoluta de que isso ia acontecer e a proteção seria concretizada e portanto, nada de ruim ia acontecer. Esta crença, embora pareça fantasiosa, proporcionou conforto e ao mesmo tempo significou que o aspecto espiritual é fator importante, independentemente do nível socioeconômico das pessoas envolvidas e serve de suporte para o enfrentamento da cirurgia cardíaca.

No aspecto Afetivo/Relacional, as reuniões possibilitaram o estabelecimento de laços afetivos entre muitos participantes e também entre eles e a enfermeira pesquisadora. As relações eram permeadas por gentileza e um grande desejo de que tudo ocorresse bem com todos. Isto ficou também evidenciado nas entrevistas finais quando os participantes dos grupos queriam saber notícias dos outros. Alguns se tornaram companheiros 
de quarto no pós-operatório aproximando ainda mais o vínculo entre eles e até entre seus familiares. A relação com a pesquisadora muitas vezes levou a um vínculo de afeição e admiração pelo trabalho que estava sendo feito. Estes mesmos participantes reconheciam que o trabalho da pesquisadora era realizado com um sentimento de carinho para com eles, o que consideravam positivo e confortante. 


\subsection{Significado da estratégia de orientação grupal na perspectiva dos participantes}

A análise estatística mostrou que os participantes dos grupos de intervenção apresentaram redução nos níveis de ansiedade e medo, estatística e clinicamente significativas, ao serem comparados ao grupo controle. Além disso, procurou-se também fazer uma análise do significado destas reuniões grupais para os participantes, a partir da entrevista final, realizada no terceiro ou quarto dia de pós-operatório.

O que se tentou elucidar com esta análise qualitativa foi compreender o efeito da estratégia utilizada para a realização da orientação pré-operatória, com a utilização de dinâmicas e da maior participação dos sujeitos naquilo que eles demandavam a respeito. Ao se considerar as respostas das questões propostas verificou-se que algumas pessoas utilizaram uma linguagem mais simples ou tiveram dificuldades para se expressar. Isto já era esperado em função da baixa escolaridade de muitas delas. Por outro lado, é de se levar em consideração a inexperiência da pesquisadora em adaptar as perguntas à condição encontrada (nível de compreensão de alguns participantes) o que também contribuiu para esta situação. De qualquer forma as entrevistas trouxeram uma riqueza de interpretações que serão comentados a seguir.

Na opinião da maioria dos participantes, a reunião grupal de orientações pré-operatórias foi mais proveitosa que se tivesse sido realizada de forma individual.

Assim, para a análise das avaliações feitas pelos participantes dos grupos de intervenção, no terceiro ou quarto dia de pósoperatório, a respeito da estratégia utilizada para a orientação pré-operatória feita de forma grupal, foram realizadas leituras cuidadosas das entrevistas. 
Destas leituras extraíram-se frases significativas que posteriormente foram agrupadas por equivalência de significados, estando apresentada na Figura 3.

Figura 3 - Esquema representacional do significado da atividade de orientação grupal

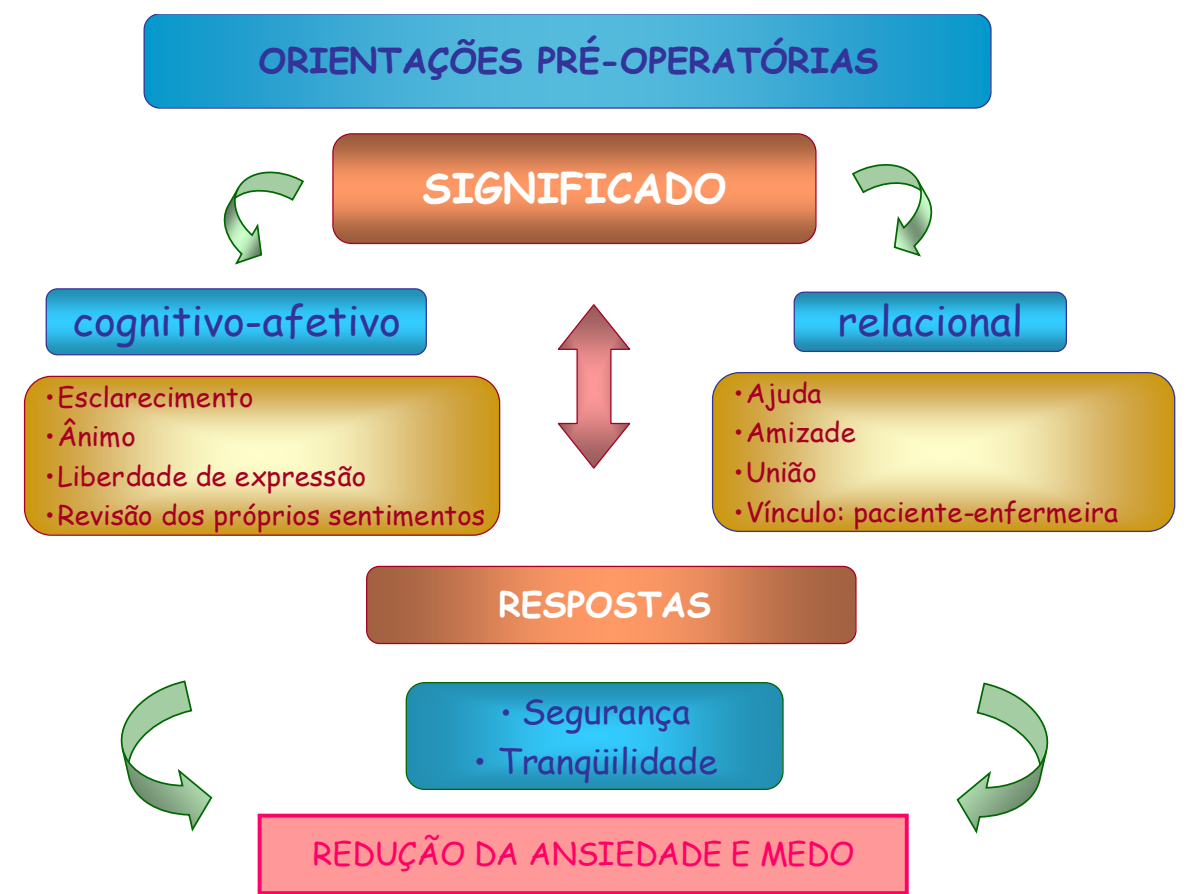

Este esquema foi construído pelo significado atribuído pelos participantes do grupo de intervenção, à participação no grupo de orientações pré-operatórias com a enfermeira pesquisadora. A maioria dos sujeitos deste estudo demonstrou um sentimento de alegria e otimismo. Mesmo aqueles que não tiveram um resultado cirúrgico satisfatório referiram que a reunião grupal os auxiliou a enfrentar o processo cirúrgico.

Enquanto algumas pessoas se lembravam com detalhes tudo que aconteceu durante a reunião grupal, outras tinham uma lembrança com menor detalhamento. Porém, à medida que se procurou resgatar a sua participação na dinâmica, as lembranças vieram à tona com significado positivo e entusiasmado. Estas pessoas procuraram influenciar a 
pesquisadora a não abandonar as reuniões da pesquisa, mas transformá-las em rotina naquela instituição. Alguns participantes chegaram a avaliar melhor a instituição a partir da reunião grupal.

Conforme a Figura 3 verifica-se que as orientações préoperatórias feitas de forma grupal teve significado Cognitivo-afetivo e Relacional.

No aspecto Cognitivo-afetivo, as respostas dos participantes foram permeadas pela afetividade. Eles descreveram sentimentos positivos que afloraram com as reuniões grupais, o que Ihes proporcionou ânimo, liberdade de expressão e a revisão dos próprios sentimentos.

Com relação ao Esclarecimento, afirmaram terem tido muitos benefícios do ponto de vista cognitivo como: orientação, conscientização, aprendizagem e solução de dúvidas. Mencionaram terem se sentido à vontade para perguntar para a enfermeira pesquisadora todas as suas dúvidas, tanto referentes aos aspectos técnicos como também aos emocionais. Nenhum dos participantes do grupo de intervenção procurou a pesquisadora em particular para esclarecer qualquer questão, apesar de essa possibilidade ter ficado em aberto como uma opção. Eles ainda afirmaram que nada deixou de ser dito ou perguntado pelo fato de estarem diante de outras pessoas além da enfermeira.

Um dos participantes trouxe de casa uma folha digitada e impressa em computador com várias perguntas organizadas em itens e subitens, para que alguém pudesse respondê-las. Ele viu na enfermeira pesquisadora a pessoa que estava the oferecendo uma oportunidade ideal para o esclarecimento de suas dúvidas e obtenção de respostas. Disse depois que se sentia esclarecido com as respostas. Este participante exigiu um tempo extra da pesquisadora além do tempo disponibilizado para o grupo de intervenção. Cabe ressaltar que era uma pessoa de nível superior 
de escolaridade que já havia lido tudo que encontrou sobre a doença, diagnóstico, tratamento, mas ainda tinha dúvidas a esclarecer.

Apenas um dos participantes afirmou que não gostaria de ter sido informado sobre o procedimento do tubo orotraqueal, pois em sua imaginação, o tubo ia impedir sua respiração. Ou seja, segundo sua fala pode-se inferir que não houve entendimento sobre a situação que ia vivenciar. Este é um problema a ser enfrentado pelos profissionais quando vão realizar orientações para pacientes com baixo nível de escolaridade, pois apesar deste problema ter sido considerado pela pesquisadora, para essa pessoa ocorreu esta falha.

As falas expressas abaixo exemplificam no aspecto Cognitivo-afetivo, o esclarecimento.

- "A gente não fica nada com dúvida ali".

- "... me senti mais preparado para a cirurgia".

- "... fiquei mais consciente do que ia acontecer comigo".

- "Eu aprendi muita coisa". trata né".

-" A gente entra aqui ninguém sabe do que se

- "Achei muito importante ter sido orientado sobre o tubo para poder manter a calma".

"... com a orientação foi melhor porque eu não sabia que ia acontecer aquilo, né".

- "...e aí nóis acorda sabendo...”

"Foi uma conversa que deixou a gente mais esclarecido..."

No que se relaciona ao Ânimo, ressalta-se que o diagnóstico de doença arterial coronariana, juntamente com a necessidade de uma intervenção cirúrgica é assustador, como já mencionou o estudo de Duarte $^{47}$. Algumas pessoas relataram que o momento da notícia foi o pior, deixando-as muito tensas, sendo que, no momento da internação para a 
concretização do ato cirúrgico, já havia passado algum tempo e o impacto inicial já havia sido absorvido.

Para outras pessoas, o desânimo aparece no momento da internação, quando há a necessidade de deixar para trás suas vidas particulares e enfrentar a situação real de cirurgia.

Para os participantes cujas falas estão descritas abaixo, a reunião grupal de orientações possibilitou a eles sentir ânimo, o que os auxiliou a enfrentar a situação.

- "Vai conversando com um e com outro vai animando nós né".

-“Todo adorei”.mundo se animou,

- "Ah! Não que eu tava desanimada, mas com aquela orientação da senhora eu animei bastante".

-"Eu acho que é melhor porque pelo menos um conversa uma coisa, outro conversa outra né, e um anima o outro né. Dá mais animação pra gente fazer a cirurgia".

A Liberdade de expressão foi apreendida pelas pessoas que participaram dos grupos ao afirmarem que tiveram a oportunidade de expressar tudo que estavam sentindo naquele momento, com liberdade. Apesar de que visivelmente alguns eram mais tímidos e falavam pouco, todos afirmaram que disseram tudo que tiveram vontade. Apenas uma pessoa comentou que gostaria de ter se colocado mais vezes para contar um pouco mais de sua história, mas segundo ela, os outros participantes falavam demais e dificultaram sua expressão. Apesar disto, ela ainda afirmou que em relação à cirurgia sentiu-se esclarecida e bem atendida.

É interessante mencionar que a empatia é um fator importante para que os pacientes sintam que podem se expressar com liberdade. Dessa forma, os sentimentos e os conflitos podem aflorar, ou seja, serem trazidos para a consciência podendo assim diminuir a ansiedade como afirma $\mathrm{May}^{3}$. Os depoimentos abaixo explicitam isso. 
- "...achei também muito importante a gente escrever o que a gente sente, tem que ser aquilo que tá no coração".

- “..eu já tava completamente vazio, já tinha esvaziado tudo que tinha que falar, o que tinha de perguntar já tinha perguntado..."

-“...aquela brincadeira, digamos assim, de deixar a pessoa mais ou menos, mais livre, me deixou mais livre ainda..."

A Revisão dos próprios sentimentos foi possível, uma vez que a reunião grupal ofereceu uma oportunidade para rever a situação vivida e elaborar um pensamento consciente sobre os próprios sentimentos. Ao mesmo tempo em que se estimulou uma identificação entre os participantes, de sentimentos e idéias relacionados à cirurgia, houve também, quem referiu não só uma tomada de consciência, mas uma revisão dos próprios valores e sentimentos a partir do discurso dos outros participantes. Afinal, as pessoas têm particularidades que as diferem, mesmo que estejam enfrentando situações equivalentes.

- "Ajuda a gente também a elaborar tudo isso. Porque será que eu tô sentindo tanto medo? O que me faz ter medo, né?"

-“...e isso eu acho que faz também com que você repense também, sabe...valores, sentimentos...

- "...a gente vê os problemas das outras pessoas né, porque a gente pensa que só a gente sofre né. Aquilo lá fortalece né".

As orientações pré-operatórias feitas no grupo de intervenção trouxeram também um Significado Relacional, no sentido de proporcionar amizade, ajuda, união e vínculo enfermeira-paciente.

Os participantes dos grupos de intervenção enfatizaram a importância de conhecer as pessoas que encontravam nos corredores, pois existia uma convivência distante e estranha que eles gostariam de modificar e não sabiam como, denotando o desejo de fazer Amizade. A reunião grupal deu a eles a oportunidade de relacionamento com outros pacientes, criando 
situações de amizade que amenizaram o ambiente hospitalar. A maioria queria informações sobre o resultado cirúrgico daqueles que conheceram nas reuniões e quando podiam faziam visitas recíprocas no período pósoperatório. As falas evidenciam essa interação. com eles".

- "...ficou parece com um laço mais de amizade

-..."às vezes a gente passava por eles e não tinha coragem de se aproximar né".

- "Foi bom conhecer outras pessoas".

- "...depois da cirurgia foi bom que hoje a gente encontra toda a turma lá"...

- "... até aquele momento eu ainda não conhecia ninguém do hospital e aí eu passei a conhecer"...

- "Tem vantagem porque você pega amizade com as pessoas e troca de idéias né".

Nesse aspecto, Costa, Leite e Sobreira ${ }^{60}$ realizaram um estudo onde parte das orientações pré-operatórias era feita em grupos. Elas comentam em seus resultados que este tipo de orientação desenvolveu um interesse recíproco entre os integrantes dos grupos, demonstrando uma coesão social intensa.

Foi apreendido também no aspecto relacional a Ajuda que os participantes obtiveram ao participar do grupo de intervenção. As pessoas descreveram que o relacionamento estabelecido dentro do grupo de intervenção criou um ambiente de ajuda mútua. Durante esta descrição um dos participantes ficou tão emocionado que precisou interromper a fala em função do choro. Este tipo de ajuda surgiu a partir de palavras de solidariedade e incentivo criadas por eles próprios, o que gerou também uma sensação de conforto. Este ambiente de solidariedade e conforto levou estas pessoas a vivenciar o que eles próprios chamaram de "força" para enfrentar a situação, conforme se observa nos depoimentos. 
-“...principalmente com as palavras de conforto que o pessoal fala, né, é uma grande coisa isso aí". chorou)

- "Um ajudando o outro". (ficou emocionado e

- "Aquilo lá fortalece né. Faz sempre isso, Denise, faz sempre".

- "Ninguém contava alegria, era sofrimento né. Mas um sofrimento que dava força pra gente. Então é muito bom! Continua Denise, continua mesmo"!

A União foi conseguida em função de que as reuniões dos grupos de intervenção possibilitaram condições para se criar o apoio emocional entre os participantes. Aqueles que se sentiam emocionalmente melhor preparados diante do processo cirúrgico proferiram palavras de apoio para aqueles que se encontravam menos preparados. Além disso, a dinâmica utilizada para realizar o fechamento da intervenção proporcionou condições para a criação de um ambiente de união entre eles pois os estimulou a verbalizar mais palavras de conforto. Alguns ficaram muito impressionados com o resultado daquela dinâmica do barbante e sentiram que uma força foi criada com a rede construída pelas pontas do barbante e sentiram o que consolidou uma união muito positiva entre eles.

- "O grupo dá força, faz a união e vai em frente".

- "Nós estávamos em quatro né, no grupo. Todos com mesmo problema, praticamente. Então um dá uma força pro outro né".

- "Não partir pra luta sozinho é muito bom".

- "...é claro que foi porque eu tava forte naquela hora ali, tava vendo que eles tava sentindo fraqueza e a gente pode transmitir a fortaleza da gente pra eles".

- "É...achei legal também aquela...aquele simbolozinho da rede, do cordão, é bem bolado aquilo ali. Ele num só...como diz, ele num só desarma a gente, tira alguma coisa que tá a gente tá com ele, como também é um relaxante".

- "Aquela corrente com o cordão achei muito interessante. Então que se passou ali foi especial". 
- "Ah! Eu lembro de tudo, mas eu gostei mais daquele negócio do cordão"...

A entrevista final gerou uma forte emoção em vários participantes. Estes falaram com a voz embargada ou chegaram mesmo ao choro. Pode-se afirmar que o próprio retorno da enfermeira pesquisadora para mais um contato na entrevista final gerava algum tipo de emoção, pois eles a recebiam com entusiasmo e satisfação. Isto denota o Vínculo estabelecido entre paciente e enfermeira.

Concorda-se aqui com Siviero ${ }^{85}$, quando afirma que 0 enfermeiro pode e deve trabalhar com os sentimentos da maioria dos pacientes hospitalizados, desde que estes não apresentem patologias psiquiátricas que dependam de profissionais especializados. Estas pessoas geralmente estão cheias de medos e inseguranças, que podem ser aliviadas por meio da comunicação interpessoal de forma empática. Este tipo de comunicação é realizado de forma muito simples, desde que o profissional se disponha a ouvir a pessoa, auxiliando-a com isto a tomar consciência de suas próprias necessidades e encontrar suas próprias formas de enfrentamento da situação.

As frases relacionadas abaixo demonstram que foi possível alcançar uma relação de confiança com os pacientes e atingir uma comunicação interpessoal por meio da empatia e do ouvir sensível.

- "Foi um braço direito pra nóis, não só pra mim, mas pra todos nóis que tava ali, sua presença, aquele seu trabalho".

- ..."foi uma pessoa boa que mesmo que a pessoa não saiba, mas dá força”.

- "Então eu agradeço muito a senhora não só por aquele momento"...

- "Porque eu tinha comentado que o anjo meu é forte né, e aí eu contei da senhora e ela falou: Então ela foi o anjo do senhor".

- "Do jeito que a senhora quiser fazer, se for a senhora, perfeito"! 
- "E todo mundo que vier me visitar eu vou contar tudo que se passou aqui, inclusive a senhora vai entrar no meio também".

- "Tem uma senhora que trabalha no centro cirúrgico, ... como que ela orienta a gente pra cirurgia, você não tem um pingo de medo, no momento ali a gente quer ir logo".

- "O que eu mais me lembro e que marcou foi seu bom atendimento e seu relacionamento, tá. Desculpe falar você, mas só de você estar presente já transmite assim...uma coisa sensacional...sei lá, deixa todo mundo à vontade né, perguntando coisas que as pessoas sentem, o que ela acha que tinha que ser, a preocupação da pessoa né. $E$ eu acho que isso daí foi muito bacana"!

Também seria interessante que esta assistência tivesse uma continuação no momento exato da cirurgia. Não foi possível para a enfermeira pesquisadora estar presente na porta do centro cirúrgico para receber todos os participantes da pesquisa no momento da entrada no centro cirúrgico. Vários deles foram recepcionados por uma outra enfermeira que eles não conheciam. Aqueles que puderam ser recebidos pela própria pesquisadora comentaram que esta presença foi importante para eles.

Cabe salientar que o ideal seria que a própria enfermeira do centro cirúrgico realizasse a visita pré-operatória e depois recepcionasse estes pacientes no centro cirúrgico para uma assistência completa. Mas sabe-se que é impossível cumprir esta tarefa com a totalidade dos pacientes operados, pois alguns estão sendo recebidos no centro cirúrgico ao mesmo tempo em que outros estão recebendo a visita pré-operatória. Mas pode-se procurar atender o máximo de pessoas que for possível, pois eles próprios citam a importância deste procedimento como fica demonstrado nas frases do quadro a seguir.

- "E eu gostei de ver você lá embaixo... é, lá na porta do centro cirúrgico".

- ...porque a pessoa que eu tinha conversado era você e você tava lá". 
-... "também tem o momento que eu entrei na

cirurgia e que foi muito bom encontrar a senhora lá...

eu adorei"!

A partir da análise dos significados apreendidos dos sujeitos da pesquisa a respeito das orientações que receberam em função da participação nos grupos de intervenção, identificou-se que a experiência possibilitou respostas favoráveis que se traduziram em segurança e tranqüilidade para o enfrentamento da intervenção cirúrgica.

A Segurança foi conseguida quando as pessoas comentaram sua satisfação em encontrar no centro cirúrgico a mesma enfermeira que havia realizado o grupo de intervenção do qual elas participaram. Percebia-se pela expressão de seus rostos, esta sensação de segurança por encontrarem uma pessoa que eles conheciam e confiavam em meio ao ambiente novo, com apenas a presença de desconhecidos.

Também se observou o sentimento de segurança, quando dois dos participantes do grupo de intervenção chegaram a afirmar na entrevista final que a enfermeira pesquisadora lhes disse para ter calma e coragem, pois não havia o que temer. Não fazia parte deste estudo induzir qualquer paciente à certeza de que nada ruim iria the acontecer durante 0 processo cirúrgico. Porém, a sensação de segurança que permaneceu após a reunião levou-os a interpretar as orientações desta forma.

A orientação parece ter transmitido esta sensação de otimismo e segurança de tal proporção, que foi criada a fantasia de que a própria pesquisadora havia lhes afirmado com palavras, que eles não corriam riscos.

No estudo de Costa, Leite e Sobreira ${ }^{60}$ sobre a importância da orientação de enfermagem no pré-operatório de pacientes com afecções cardíacas ficou patente que, o esclarecimento pré-operatório proporciona maior segurança e participação no tratamento.

As frases destacadas a seguir explicitam a segurança. 
- "Ah, eu senti firmeza, né"...a gente sente uma firmeza do que vai acontecer..."

- "Foi que a senhora falou que a gente tem que ter coragem..."

- "O que eu lembro é que a senhora falou que não era pra ter medo porque o negócio lá...a coisa era bem feita."

A tranqüilidade foi outra resposta encontrada a partir dos discursos dos próprios participantes dos grupos de intervenção. A orientação parece determinar não só o sentimento de segurança, mas o de tranqüilidade também. Tanto a reunião, quanto o diálogo estabelecido com as pessoas presentes foram determinantes para proporcionar tranqüilidade em relação ao ato cirúrgico.

-"Eu fui para a cirurgia tranqüilo."

-“...e eu entrei lá na cirurgia numa tranqüilidade tremenda."

-"A reunião me deixou mais tranqüila em relação à cirurgia."

- Achei bom ser orientado sobre o tubo pra poder manter a calma lá na hora..."

-"Fiquei mais tranqüilo depois da reunião." já estava."

-“...aquilo ali me deixou mais tranqüilo do que eu

-“...pega a opinião de um, uma informação de outro e a pessoa vai ficando mais tranqüila né."

- "Então quando eu fui pra cirurgia eu achei que eu tava mais tranqüila".

- ..."eu fui com uma tranquilidade incrível"!

Como resultados das respostas de segurança e tranqüilidade e de todo o processo vivenciado e avaliado pelos participantes do estudo obteve-se a Redução da ansiedade e do medo.

A redução da ansiedade e do medo se deu em função de que os participantes do grupo de intervenção referiram ter enfrentado o 
processo cirúrgico com o nível de ansiedade e medo diminuídos. Isto se deveu ao fato de terem se sentido mais informados, obtiveram esclarecimentos para suas dúvidas, interagiram com os outros participantes e com a enfermeira pesquisadora, além de terem conseguido a descontração com a utilização das dinâmicas que ocorreram de forma lúdica e expressiva.

Num estudo realizado por Kiyohara LY et $\mathrm{al}^{30}$, sobre pacientes em pré-operatório ficou demonstrado que o simples fato de o paciente ter informação sobre a cirurgia já diminuía sua ansiedade.

Na presente pesquisa, as informações sobre a cirurgia foram dadas a partir das dúvidas dos próprios participantes. Com o primeiro jogo, o do nome, a enfermeira pesquisadora inseriu cada paciente dentro do grupo pedindo que discorressem a respeito do próprio nome. Isto abriu uma oportunidade para que falassem um pouco sobre suas próprias histórias e se colocassem como personalidades dentro do grupo. Mesmo pessoas que se comportaram de forma mais tímida durante a reunião, referiram ter tido oportunidade de esclarecer suas dúvidas e ter descontraído em relação ao processo cirúrgico.

Durante as reuniões grupais, além de resolver dúvidas a respeito da cirurgia em discurso sério e informativo, os participantes tiveram a oportunidade de "brincar", ou seja, discorrer sobre seus sentimentos de forma lúdica, induzidos por jogos simples.

Desta forma, como já ficou demonstrado na análise quantitativa, as reuniões de orientações grupais realizadas neste estudo foram eficientes para diminuir a ansiedade e o medo no pré-operatório, sendo que as falas corroboram e exemplificam essa diminuição.

- "Fazer uma brincadeirinha, bater um papo, isso aí acaba com a ansiedade"... tranqüilo".

- "Fui para o centro cirúrgico totalmente 


\section{tranquilidade tremenda". \\ - "Fez nóis descontrair"... \\ - ..."a gente sai com a mente mais leve". \\ - "Eu acho que alivia, deixa menos nervosa". \\ - ..."fui sossegada, não tive medo". \\ - ..."quando a gente acha alguém que explica e foi tudo como foi explicado, não tive medo".}

- "Eu perdi um pouco daquela cisma, aquela emoção né, e também perde o medo"...

- "Cheguei no quarto e falei pra minha neta: agora não tô mais com medo"... medo"

- ..."me esclareceu tanta coisa que acabou o

- ..."eu disse pro rapaz aí...pra ele participar...que ele diga tudo que ele sinta pra ele não ir com medo".

Salvarini e Mendes $^{86}$ afirmam em sua pesquisa sobre a comunicação do enfermeiro com o paciente e as expectativas destes nas situações de medo e tensão, que o indivíduo espera por alguém que simplesmente o deixe falar e que tenha tempo disponível e interesse por aquilo que ele tem a dizer; desta forma as tensões são controladas e o paciente sente-se mais relaxado. Estas pesquisadoras também comentam que nas situações de medo e tensão, comuns nos pacientes cirúrgicos, é fundamental qualquer atitude junto ao paciente que o auxilie a ter equilíbrio e harmonia internos.

É conveniente mencionar que o processo de dar orientações pré-operatórias em grupo utilizando várias dinâmicas como estratégia ocupou em média o tempo de duas horas da enfermeira pesquisadora, o que demonstrou uma otimização do tempo para os profissionais que realizam a visita pré-operatória de enfermagem.

Ao se considerar este tempo, não se pode esquecer que para esta pesquisa contou-se com o apoio de um manual de orientações 
pré-operatórias que os participantes do grupo puderam ler antes da reunião. Desta forma, não houve necessidade de prestar muitas orientações técnicas, apenas foram esclarecidas as dúvidas. Aqueles que não podiam ler por algum motivo contaram com a ajuda de parentes, de outros pacientes e também da enfermeira pesquisadora.

Verificou-se que o importante é reunir um grupo que vai fazer o mesmo tipo de cirurgia, como foi o caso da cardíaca, pois as orientações são as mesmas para todos os pacientes. Porém, houve a participação de pacientes que iam passar por procedimentos que não necessariamente seria a de revascularização do miocárdio, como a cirurgia para troca de valva cardíaca ou uma segunda intervenção em coronária. Este último ainda estava fora da faixa etária para inclusão no estudo, porém permitiu-se a participação por terem sido convidados pelos próprios sujeitos da pesquisa. A enfermeira pesquisadora não negou a participação, apenas não os incluiu na coleta de dados do estudo. Por estas outras participações pôde-se perceber de maneira empírica que o grupo de intervenção pode abranger estes outros tipos de pacientes com bons resultados de entrosamento e satisfação.

Pela experiência que este estudo permitiu, não pareceu haver necessidade de se constituir grupos tão restritos como foram os dessa pesquisa. Os resultados obtidos indicaram que existe uma condição básica entre todos eles que é o fato de que se submeterão a uma cirurgia cardíaca. O tipo da cirurgia não determinou mudanças em relação às expectativas e às reais necessidades de orientação. Assim, os pacientes de cirurgia de revascularização miocárdica poderiam se misturar àqueles que vão passar pelo procedimento de troca de valva ou então uma aneurismectomia de aorta ou de ventrículo esquerdo.

Em situações que requeiram as re-operações, como no caso da pessoa que desejou participar da reunião, Fighera e Viero ${ }^{87}$ encontraram em seu estudo, que o fato de o paciente já ter passado por experiências positivas em relação à cirurgia não amenizam o medo, ou seja, a ansiedade 
surge independente do número de cirurgias a que o paciente se submeteu. Cada cirurgia é vivenciada como única, mesmo quando já conhece os procedimentos técnicos.

Com as dinâmicas utilizadas, os pacientes sentiram-se à vontade para falar de seus problemas em relação ao processo cirúrgico, tendo sido atendidos individualmente em suas colocações. Em nenhum momento houve qualquer menção a uma necessidade de contato individual com a enfermeira para esclarecimento de dúvidas ou outro tipo de diálogo.

Assim, receber as orientações pré-operatórias de forma grupal, com a utilização de jogos e dinâmicas, foi muito positivo na avaliação dos próprios participantes. Muitos chegaram a ser efusivos no momento de avaliar. Outros, talvez mais tímidos, manifestaram-se de forma mais séria. Não houve críticas ou avaliações negativas.

Vale mencionar o estudo de Aiub; Wiehe; Rotert; Barraz; Ruschel ${ }^{88}$ quando afirmam que a "melhor maneira de o paciente enfrentar e poder encarar sua situação de forma consciente e objetiva é podendo falar, discutir, refletir, aceitando-a ou superando-a, conforme suas características e os recursos à sua disposição". Elas ainda completam que o "fato de os pacientes terem o mesmo tipo de patologias, referirem problemas semelhantes, enfrentarem as mesmas vicissitudes e necessidades, contribui para formar um forte clima de coesão grupal e mútua solidariedade entre os mesmos. Isso faz com que os pacientes logo ao ingressarem no grupo sintam enorme alívio ao perceber que os outros também têm o mesmo tipo de fantasias, passam pelos mesmos desânimos, em resumo, têm problemas que eles pensavam que só ocorriam com eles. A partir do momento em que se informa o paciente da situação pela qual ele irá passar, aumenta seu controle sobre a situação e isso ajuda a diminuir a ansiedade".

Vale ressaltar novamente a pesquisa de Mezzanotte $^{5}$ realizada em 1970, que embora antiga para os estudos acadêmicos da área da saúde, é perfeitamente atual dentro das nossas vivências hospitalares. 
Este foi o primeiro estudo encontrado na literatura pesquisada realizado por uma enfermeira, que teve como intuito primordial a realização de orientações pré-operatórias em grupos de pacientes que iam passar pelo mesmo tipo de procedimento cirúrgico, que no caso era cirurgia abdominal. Esta profissional utilizou esse procedimento grupal para economia de tempo e encontrou diversas vantagens. Das 23 pessoas entrevistadas por ela, 20 referiram preferência pelas orientações grupais e todas as 23 afirmaram que se tiverem parentes ou amigos em situação pré-cirúrgica vão recomendar as orientações grupais. Estas mesmas pessoas comentaram algumas vantagens de uma reunião grupal, quando outros pacientes sugerem coisas que eles próprios não haviam pensado. Também o fato de encontrar outras pessoas na mesma situação faz com que eles se sintam que não estão sós.

Quando as pessoas que participaram deste presente estudo foram questionadas se as orientações de forma grupal foram satisfatórias ou se prefeririam que tivesse sido de forma individual, 25 delas afirmaram preferir em grupo, da forma que foi feito e, 5 declararam-se indiferentes; nenhuma delas afirmou preferir um trabalho individual. Os que preferiram em grupo comentaram que os indivíduos do grupo se apóiam mutuamente, ou com palavras, ou apenas porque estão dividindo o mesmo tipo de problema. A lembrança da experiência grupal gerou forte emoção em alguns, chegando a provocar choro. Vários participantes fizeram questão de incentivar a implantação definitiva da intervenção grupal, pois se sentiram ajudados. 
A maior parte dos sujeitos desta pesquisa era do sexo masculino (70\%), com Ensino Fundamental Incompleto (53,3\%) e estrato sócio-ocupacional médio (28,3\%). A idade foi pré-estabelecida como critério de inclusão, entre 55 e 70 anos, sendo que os participantes ficaram distribuídos de forma equivalente no grupo intervenção e controle.

Confirmando a hipótese inicial, os participantes dos grupos de intervenção referiram menor nível de ansiedade e de medo no momento 2 (pré-operatório imediato) que os do grupo controle. A diferença foi estatisticamente significativa com $p=0,02$ para ansiedade e $p=0,01$ para medo. Esta diferença também foi clinicamente significante com $E S=0,65$ tanto para ansiedade quanto para medo.

$\mathrm{Na}$ comparação entre os grupos ao longo dos três momentos verificou-se que no grupo de intervenção os escores de ansiedade foram estatisticamente diferentes entre si. No grupo controle houve diferença estatisticamente significante entre o segundo e 0 terceiro momentos.

A mudança nos níveis de ansiedade entre o primeiro e o segundo momento foi clinicamente mais significante no grupo de intervenção $(E S=0,44)$ que no controle $(E S=0,14)$.

As dinâmicas utilizadas como estratégia de intervenção nos grupos de orientação pré-operatória proporcionaram um momento lúdico com descontração, ambientação hospitalar e ocupação do tempo ocioso e um momento expressivo, propiciando expressões no âmbito técnico, espiritual e afetivo/relacional. 
As reuniões de orientações pré-operatórias trouxeram significados cognitivo-afetivo e relacional. Quanto ao cognitivo-afetivo as pessoas referiram o esclarecimento, o ânimo, a liberdade de expressão e a revisão dos próprios sentimentos. No significado relacional foram vivenciadas situações de amizade, ajuda, união e o vínculo pacienteenfermeira.

Como respostas desses significados as pessoas referiram segurança e tranqüilidade. O efeito final da situação vivenciada foi a redução do nível de ansiedade e de medo. 
Os resultados obtidos com este estudo mostraram que houve redução dos níveis de ansiedade e medo no grupo que participou da estratégia de intervenção, na abordagem psicossocial, ao ser comparado ao grupo controle.

A abordagem psicossocial do grupo ofereceu aos participantes a oportunidade para se expressarem, para entrarem em contato com seus próprios sentimentos e trazê-los para o nível consciente e, assim, expô-los ao grupo. Essa exposição foi possível uma vez que se sentiram em ambiente relaxado, interativo e de confiança, proporcionado pelas dinâmicas. Cabe ressaltar que a condição para verbalizar as emoções em relação à cirurgia nem sempre é possibilitada no meio familiar, social ou institucional, o que contribui para que alguns temores permaneçam escondidos. Desse modo, a riqueza das reuniões grupais permitiu o contato e o encontro de pessoas de diferentes condições sócio-econômicas e culturais porém que vivenciavam momentos singulares e ao mesmo tempo comuns a todos, ou seja, a necessidade iminente da cirurgia de revascularização do miocárdio. Estas pessoas estimuladas puderam se expressar e refletir, se aproximaram e se apoiaram mutuamente, diminuindo os sentimentos negativos.

A abordagem permitiu também a criação de vínculo com a enfermeira pesquisadora. Isto pode ser alcançado por qualquer pessoa que se proponha a se dedicar a um trabalho junto aos pacientes. A atitude de possibilitar uma escuta sensível foi fundamental para se atingir a finalidade da pesquisa.

Tal situação remete à oportunidade de vivenciar um exercício profissional mais pleno, pois o enfermeiro se desobrigada da realização de uma tarefa repetitiva de orientações pré-operatórias 
tradicionais, que geralmente abordam os aspectos técnicos e que precisam ser repetidas várias vezes ao dia. Acredita-se que a orientação repetitiva é um dos motivos que desestimula os enfermeiros a realizarem a visita préoperatória.

Por ser pesquisa, foi necessário o controle mais ou menos rígido das situações grupais, para que houvesse parâmetros de comparações e avaliações. Porém, no exercício cotidiano o profissional pode trabalhar com uma gama maior de opções de dinâmicas grupais, adaptando às situações de cada grupo, a fim de estimular as expressões das pessoas e talvez alcançar resultados ainda melhores. Desta forma, a criatividade do profissional pode ser exercida de forma ampla para atingir os objetivos propostos em sua abordagem de orientações pré-operatórias

Na síntese geral, os resultados obtidos na pesquisa indicam que as orientações pré-operatórias realizadas de forma grupal, na abordagem psicossocial, produzem resultados efetivos e, portanto, recomenda-se que essa estratégia seja implementada nas instituições hospitalares. 
... "Então a minha ansiedade era justamente isso daí, como você fazer uma cirurgia no coração que é um órgão muito delicado né, é uma das principais coisas que nós temos em todo o nosso organismo e que dá muita preocupação."... 


\section{ANEXO 1 \\ Instrumento de Coleta de Dados}

\section{I-Identificação}

Nome: Registro Hospitalar:

Idade: Sexo: Ocupação:

Escolaridade: Ensino fundamental ( ) completo ( ) Incompleto Ensino médio ( ) completo ( ) Incompleto Ensino superior ( ) completo ( ) Incompleto

\section{II - Nível de ansiedade}

- Em relação à cirurgia o seu nível de Ansiedade é:

( ) Muito alto ( ) Alto ( ) Médio ( ) Baixo ( ) Muito baixo ( ) Inexistente

\section{III - Nível de medo}

- Em relação à cirurgia, o seu nível de medo é:

( )Muito grande ( )Grande ( )Médio ( )Pequeno ( )Muito pequeno ( ) Inexistente 


\section{ANEXO 2 \\ TERMO DE CONSENTIMENTO LIVRE E ESCLARECIDO}

Eu

declaro que, após ter sido convenientemente esclarecido(a) pela enfermeira Maria Denise Leon, aluna de mestrado do Programa de Pós-Graduação em Enfermagem na Saúde do Adulto, da Escola de Enfermagem da USP, consinto em participar da pesquisa intitulada "Ansiedade e medo no pré-operatório de cirurgia cardíaca: intervenção de enfermagem na abordagem psicossocial" orientada pela $\operatorname{Prof}^{\mathrm{a}}$. $\mathrm{Dr}^{\mathrm{a}}$. Vilanice Alves de Araújo Püschel que tem como objetivos : identificar os níveis de ansiedade e de medo nas pessoas que vão se submeter à cirurgia de revascularização do miocárdio $(\mathrm{RM})$ / implementar uma estratégia de orientação grupal na visita préoperatória, na abordagem psicossocial, para as pessoas que apresentarem medo e ansiedade no pré-operatório de cirurgia de RM / comparar os níveis de ansiedade e medo entre os indivíduos que receberam as orientações tradicionais da instituição e aqueles que participaram da estratégia grupal de intervenção / avaliar a estratégia de orientação grupal na visita pré-operatória, segundo a percepção das pessoas participantes do grupo.

Sei que as informações são sigilosas e serão obtidas por meio de minha resposta a um questionário e pela participação ou não em uma atividade de grupo com outras pessoas que também se submeterão à cirurgia cardíaca.

Sei que receberei as orientações pré-operatórias fornecidas pela instituição ou pela enfermeira pesquisadora, sem haver prejuízo para o meu tratamento.

Sei que serei abordado pela pesquisadora em três momentos para responder a um questionário no período pré e pós-operatório.

Sei que não receberei qualquer remuneração para participar desta pesquisa.

Sei que estes dados serão utilizados exclusivamente para esta pesquisa e esta contribuirá para melhorar as orientações de enfermagem às pessoas que se submeterão à cirurgia cardíaca. Sei que tenho liberdade para participar e para retirar o consentimento em qualquer fase da pesquisa, sem qualquer prejuízo para a assistência que tenho recebido nesta Instituição e que será garantido o sigilo da minha identidade.

Sei, também, que terei acesso aos resultados, caso tenha interesse, com a posterior publicação da pesquisa ( Conforme Resolução 196 de 10/10/1996).

$$
\text { São Paulo, de de } 2006 .
$$

Assinatura do(a) participante da pesquisa: RG:

Assinatura da pesquisadora: $R G$ :

Contato com a pesquisadora: Maria Denise Leon. Instituto Dante Pazzanese de Cardiologia. Telefone: 5085-4116.

Comitê de Ética em Pesquisa do Instituto Dante Pazzanese - Telefone: 5085-4040

$$
\text { Uma via - Pesquisadora Uma via pesquisa - Participante da Pesquisa }
$$


ANEXO 3 
Referências Bibliográficas

(1) Mc Reynolds P. The concept of anxiety: background and current issues. In: Byrne DG; Rosenman RH. Anxiety and the heart. USA: Hemisphere Publishing Corporation; 1990. p. 3-22.

(2) Spielberger CD, Saranson IG. Stress and anxiety. Washington, DC.: Hemisphere Publishing Corporation; 1975; 1(6).

(3) May R. O significado de ansiedade. As causas da integração e desintegração da personalidade. Trad. De Álvaro Cabral. Rio de Janeiro: Zahar; 1977.

(4) Cabral A, Nick E. Dicionário técnico de psicologia. $11^{\text {a }}$ ed. São Paulo: Cultrix; 1974.

(5) Mezzanotte EJ. Group instruction in preparation for surgery. Am J Nurs jan. 1970; 70(1):89-91.

(6) Schmitt FE, Wooldrige PJ. Psychological preparation of surgical patients. Nurs Res 1973; 22(2):108-116.

(7) Christopherson B, Pfeiffer C. Varying the timing of information to alter preoperative anxiety and postoperative recovery in cardiac surgery patients. Heart Lung Sept-Oct 1980; 9(5):854-861.

(8) Bianchi ERF, Castellanos BEP. Considerações sobre a visita préoperatória do enfermeiro de centro cirúrgico: resenha da literatura estrangeira. Rev Paul Enf 1983; 3(5):161-165.

(9) Khun EH, Kruse MHL, Ruschel PP, Dovera TS. Grupo de pacientes de cirurgia cardíaca - relato de experiência. Rev Bras Enf abr-set 1986; 39(2/3):76-80.

(10) Pagliuca LMF. Problemas dos pacientes em pós-operatório de cirurgia cardíaca, na UTI - Intervenção de enfermagem [doutorado]. São Paulo: Escola de Enfermagem, Universidade de São Paulo; 1986.

(11) Zen OP, Brutscher SM. Humanização: enfermeira de centro cirúrgico e o paciente de cirurgia. Enfoque 1985; 14(1):4-6. 
(12) Hayashi ELO, Januncio IM, Santos MA, Franzosi FM. Visita préoperatória do centro cirúrgico - Teste piloto para implantação. Hospital Administração e Saúde 1987; 11(41):18-21.

(13) Silva A. A visita pré-operatória de enfermagem pela enfermeira do centro cirúrgico. Rev Esc Enf Universidade de São Paulo ago 1987; 21(2):145-157.

(14) Castellanos BEP, Jouclas VMG. Assistência de enfermagem perioperatória: um modelo conceitual. Rev Esc Enf Universidade de São Paulo dez 1990; 24(3): 359-370.

(15) Bittar E, Maria VLR. Sistematização da assistência de enfermagem no período perioperatório de um hospital especializado em cardiologia. Rev SOCESP mar-abr 1993; 3(2)(supl A):3-7.

(16) Zago MMF. Considerações sobre o ensino do paciente cirúrgico. Rev Esc Enf Universidade de São Paulo abr 1993; 27(1):67-71.

(17) Caldonha AM, Mendes IAC. Levantamento das necessidades préoperatórias do paciente cirúrgico em um hospital da rede privada de Ribeirão Preto. Simpósio Brasileiro de Comunicação em Enfermagem; 1998; Ribeirão Preto: Escola de Enfermagem de Ribeirão Preto, Universidade de São Paulo.

(18) Pellizzetti N, Bianchi ERF. Visita pré-operatória de enfermagem: análise retrospectiva. Rev SOBECC jan-mar 1999; 4(1):24-28.

(19) Baggio MA, Teixeira A, Portella MR. Pré-operatório do paciente cirúrgico cardíaco: a orientação de enfermagem fazendo a diferença. Rev Gaúcha Enferm jan. 2001; 22 (1) 122-139.

(20) Jorgetto GV, Noronha R, Araújo IEM. Estudo da visita pré-operatória de enfermagem sobre a ótica dos enfermeiros de centro cirúrgico de um hospital universitário. Revista Eletrônica de Enfermagem [periódico online] 2004; 6(2). Disponível em: http//www.fe.ufg.br (15 jul 2005)

(21) Lepczyk M, Raleigh EH, Rowley C. Timing of preoperative patient teaching. J Adv Nurs 1990; 15:300-306.

(22) Peniche A de CG. A influência da ansiedade na resposta do paciente no período pós-operatório imediato [tese]. São Paulo: Escola de Enfermagem, Universidade de São Paulo; 1998.

(23) Vargas HS, Vargas CO, Mendes MCM, Villar RFN, Haas SN. Contribuição ao estudo dos aspectos psicológicos que influenciam no pré e pós-operatório da cirurgia cardíaca. Ars Curandi Cardiologia 1983; $2^{\mathrm{a}}$ parte; 5(33):10-22. 
(24) Cordeiro ALAO, Santos JMC dos, Morais M do CB de, Teles MJS, Aguiar MP de. Apoio psicológico ao paciente - uma prioridade da assistência de enfermagem. Rev Baiana Enf 1986; 2(1):119-135.

(25) Ismael SMC, Perissé PM. Orientação para cirurgia, manutenção da saúde e prevenção da doença no serviço de psicologia do Hospital do Coração. Atualização Cardiol 1988; 2:12-15.

(26) Fontes M de CC, Almeida M do S, Carvalho DD de. O trauma cirúrgico: importância da orientação pré-operatória. Rev Bras Enf 1980; 33:194-200.

(27) Medeiros VCC. Paciente cirúrgico: a influência da ansiedade nas estratégias de enfrentamento utilizadas no período pré-operatório [dissertação]. São Paulo: Escola de Enfermagem, Universidade de São Paulo; 2002.

(28) Salmon P. Anxiety and stress in surgical patients. Br J Hosp Med 1992; 48(9):531-533.

(29) Phippen ML. Nursing assessment of preoperative anxiety. AORN J 1980; 31(6):1019-1026.

(30) Kiyohara LY; Kayano LK; Oliveira ML; Yamamoto MU; Inagaki MM; Ogawa NY, Gonzáles PESM; et al. Surgery Information reduces anxiety in the pré-operative period. Rev. Hosp. Clín. Fac. Med. S. Paulo 2004; 59(2):51-56.

(31) Panza AMM. Efeito da visita pré-operatória da enfermeira de centro cirúrgico sobre o estresse do paciente no período pré-operatório, no dia da cirurgia e no pós-operatório [dissertação]. São Paulo: Escola de Enfermagem, Universidade de São Paulo; 1977.

(32) Ferraz ER, Salzano SDT. O paciente cirúrgico: suas expectativas e opiniões quanto ao cuidado de enfermagem no período transoperatório. Rev Bras Enf 1982; 35:48-59.

(33) Silva A. Percepção dos enfermeiros a respeito do apoio emocional oferecido aos pacientes cirúrgicos [dissertação]. São Paulo: Escola de Enfermagem, Universidade de São Paulo; 1989.

(34) Galdeano LE, Rossi LA, Nobre LF, Ignácio DS. Diagnóstico de enfermagem de pacientes no período transoperatório de cirurgia cardíaca. Rev Lat Am Enfermagem 2003; 11(2).

(35) Santos SSC; Luis MAV. A relação da enfermeira com o paciente cirúrgico. 2 $2^{\mathrm{a}}$ ed. Goiânia: AB; 2002. 
(36) Menezes AR. A problemática de enfermagem dos pacientes no período transoperatório - Um estudo dos problemas sentidos e observados [dissertação]. São Paulo: Escola de Enfermagem, Universidade de São Paulo; 1978.

(37) Rodrigues Al. O paciente no sistema centro cirúrgico - um estudo sobre percepções e opiniões de pacientes em relação ao período transoperatório. Rev Esc Enf Universidade de São Paulo 1984; 18(2):163-176.

(38) Santos JMCS, Morais M do CB de, Teles MJS, Aguiar, MP de, Cordeiro ALAO. Assistência de enfermagem ao paciente no trans-operatório. Rev Baiana Enferm dez 1986; 2(2):118-150.

(39) Sebastiani RW. Atendimento psicológico no CTI (O paciente cirúrgico). In: Angerami - Camon VA, organizador, Trucharte FAR, Knijnik RB, Sebastiani RW. Psicologia hospitalar Teoria e prática. $4^{\mathrm{a}}$ ed. São Paulo: Pioneira; 1999.

(40) Peniche A de CG, Chaves EC. Algumas considerações sobre o paciente cirúrgico e a ansiedade. Rev Lat Am Enfermagem jan 2000; 8(1):45-50.

(41) Pessini L, Bianchi ERF. Ética em centro cirúrgico: algumas reflexões. In: Anais da $4^{a}$ Jornada de Enfermagem em CC; 1990; São José do Rio Preto: ABEn- Seção-R. Preto 1990. p. 84-95.

(42) Byrne DG. Anxiety and the heart: a psychological perspective. In: Byrne $\mathrm{DG}$; Rosenman $\mathrm{RH}$. Anxiety and the heart. USA: Hemisphere Publishing Corporation; 1990. p. 483-9.

(43) Aristóteles. Histoire des Animaux. Paris: J. Vrin; 1957.

(44) Porto CC. Doenças do coração / Prevenção e Tratamento. Rio de Janeiro: Guanabara Koogan; 1998.

(45) Jung CG. O Homem e seus Símbolos. Trad. De Maria Lúcia Pinho. $2^{\mathrm{a}}$ ed. Rio de Janeiro: Nova Fronteira; 1964.

(46) Alexander C, Schrader E, Kneedler J. Preoperative visits: The OR nurse unmasks. AORN J 1974; 19(2).

(47) Duarte ALCB. Cirurgia cardíaca: uma abordagem psiquiátrica. In: Zimmermann D, coordenador. Temas de psiquiatria. Porto Alegre: Artes médicas; 1980. 
(48) Bastion T da F; Pereira M da P; Catão EC; Duarte WF. Um estudo sobre a ansiedade e a depressão em cardiopatas pré e pós-cirúrgicos. In: Anais do V Encontro Mineiro de Avaliação Psicológica: teorização e prática [e] VIII Conferência Internacional Avaliação Psicológica: formas e contextos. São Paulo: Vetor; 2002. p. 297-299.

(49) Svartman B. Adoecer do coração: visão psicanalítica. Rev Soc Cardiol Estado de São Paulo 1994; 4(1) (supl A) p. 5-8.

(50) Silva MDAA; Rodrigues AL; Cesaretti IUR. Enfermagem na unidade de centro cirúrgico. $2^{\mathrm{a}}$ ed. São Paulo: EPU, 1997.

(51) Silva AL. A vida por um fio, a doença que ataca silenciosamente: desvendando as representações de pessoas portadoras de doença arterial coronária e repensando a assistência de enfermagem [tese]. São Paulo: Escola de Enfermagem, Universidade de São Paulo; 2000.

(52) Castellanos BEP, Jouclas VMG, Gatto MAF. Assistência de enfermagem no período transoperatório. Enfoque 1986; 14(1):7.

(53) Zago MMF. O ritual de orientação de pacientes pelos enfermeiros cirúrgicos: um estudo etnográfico [tese]. Ribeirão Preto: Escola de Enfermagem de Ribeirão Preto, Universidade de São Paulo; 1994.

(54) Püschel VA de A. Abordagem construtivista no desenvolvimento de competências psicossociais para a assistência domiciliar [tese]. São Paulo: Escola de Enfermagem, da Universidade de São Paulo; 2003.

(55) Close A. Patient education: a literature review. J Adv Nurs 1988; 13:203213.

(56) ) Capra F. O ponto de mutação. Trad. De Álvaro Cabral. São Paulo: Cultrix; 1982.

(57) Kubo KM, Colombo RCR, Gallani MCBJ, Noronha R. Subsídios para a assistência de enfermagem a pacientes com valvopatia mitral. Rev Lat Am Enfermagem 2001; 9(3).

(58) Armelin MVAL. Apoio emocional às pessoas hospitalizadas [dissertação]. Ribeirão Preto: Escola de Enfermagem de Ribeirão Preto, Universidade de São Paulo; 2000.

(59) Smeltzer SC, Bare BG. Brunner \& Suddarth Tratado de enfermagem médico- cirúrgica. $2^{2}$ ed. Rio de Janeiro: Guanabara Koogan; 2002.

(60) Costa ZS, Leite JL, Sobreira NR. A importância da orientação de enfermagem no pré-operatório de pacientes com afecções cardíacas. Enfoque 1980; 9(3)4-8. 
(61) Araújo IEM, Noronha R. Comunicação em enfermagem: visita préoperatória. Acta Paul Enf maio-ago 1998; 11(2):35- 44.

(62) Lindeman CA. Nursing intervention with the presurgical patient. Effectiveness and efficiency of group and individual preoperative teaching phase two. Nurs Res may-june 1972; 21(3):196-209.

(63) Carpenito L J. Planos de cuidados de enfermagem e documentação: diagnósticos de enfermagem e problemas colaborativos. Trad. Ana Maria Vasconcellos Thorell. 2ªed. Porto Alegre: Artmed; 1999.

(64) Lane STM. A psicologia social e uma nova concepção do homem para a psicologia. In: Lane STM / Codo W (organizadores) Psicologia social. O homem em movimento. $2^{\mathrm{a}}$ ed. São Paulo: Brasiliense; 1985.

(65) Ide CAC, De Domenico EBL. Ensinando e aprendendo um novo estilo de cuidar. São Paulo: Atheneu; 2001.

(66) Grandesso MA. Sobre a reconstrução do significado: uma análise epistemológica e hermenêutica da prática clínica. São Paulo: Casa do Psicólogo; 2000.

(67) Piletti N. Psicologia educacional. São Paulo: Ática; 1980.

(68) Ide CAC, coordenadora. Plano regional de desenvolvimento de estratégias psicossociais para a promoção da saúde do adulto em situações de risco. São Paulo: Escola de Enfermagem da Universidade de São Paulo; 2002.

(69) Castiel LD. A medida do possível... saúde, risco e tecnobiociências. Rio de Janeiro: Fiocruz; 1999.

(70) Falcone EM de O. A avaliação de um programa de treinamento da empatia com universitários [tese]. São Paulo: Instituto de Psicologia, Universidade de São Paulo; 1998.

(71) Fletcher RH; Fletcher SW. Epidemiologia clínica. Elementos essenciais. Trad. de Bruce B. Duncan, Maria Inês Scmidt. 4ª ed. São Paulo: Artmed, 2006.

(72) Minayo MC de S. O desafio do conhecimento. Pesquisa qualitativa em saúde. 6를 ed. São Paulo: Hucitec; Rio de Janeiro: Abrasco; 1999.

(73) Monteiro R. organizadora. Técnicas fundamentais do psicodrama. São Paulo: Brasiliense; 1993. 
(74) Oliveira MK; Rego TC. Yygosty e as complexas relações entre cognição e afeto. In: Arantes VA, organizadora. Afetividade na escola: alternativas teóricas e práticas. São Paulo: Summus; 2003. 13-34.

(75) Costa-Neto PLO. Estatística. São Paulo: Edgard Blücher; 1977. p.133.

(76) Wyrwich KW, Bullinger M, Aaronson N, Hays RD, Patrick DL, Symonds T; The Clinical Significance Consensus Meeting Group. Estimating clinically significant differences in quality of life outcomes. Qual Life Res. mar 2005;14(2):285-95.

(77) Cohen J. Statistical power analysis for the behavioral sciences. 2nd ed. Hillsdale NJ: Erlbaum; 1988.

(78) Bardin L. Análise de conteúdo. Trad. de Luiz Antero Reto e Augusto Pinheiro. Lisboa: Edições 70; 1977.

(79) Brasil. Ministério da Saúde (SIH/SUS). Procedimentos hospitalares do SUS. Grupo: cirurgia de revascularização miocárdica. Disponível em: http://www.datasus.gov.br (6 abr 2005)

(80) Luz PL; Solimene MC. Peculiaridades da doença arterial coronária na mulher. Rev Assoc Med Bras 1999; 45(1).

(81) Brasil. Instituto Brasileiro de Geografia e Estatística. Síntese de indicadores sociais. Brasília; 2006. Disponível em: http//www.ibge.org.br

(82) Jannuzzi P de M. Estratificação socioocupacional para estudos de mercado e pesquisa social no Brasil. São Paulo em Perspectiva 2003; 17:(34).

(83) Laurenti R; Buchala CM; Caratin CVS. Doença isquêmica do coração: internações, tempo de permanência e gastos: Brasil, 1993 a 1997. Arq. Bras. Cardiol. 2000; 74(6):483-7.

(84) Peniche A de CG. A ansiedade e o paciente cirúrgico: análise das variáveis intervenientes [tese]. São Paulo: Escola de Enfermagem, Universidade de São Paulo; 2005.

(85) Siviero IMPS. O indivíduo infartado [dissertação]. Ribeirão Preto: Escola de Enfermagem de Ribeirão Preto, Universidade de São Paulo; 1997.

(86) Salvarini M de CC; Mendes IAC. Comunicação enfermeiro-paciente: expectativas nas situações de medo e tensão. In: Anais do 3ํ SIBRACEn. Ribeirão Preto; 1992.

(87) Fighera J; Viero EV. Vivências do paciente com relação ao procedimento cirúrgico: fantasias e sentimentos mais presentes. Rev SBPH 2005; 9(3):51-63. 
(88) Aiub ALC; Wiehe H; Rotert R; Barraz ACG; Ruschel PP. Ansiedade em pacientes cardíacos pré-cirúrgicos. Rev Soc Cardiol Estado de São Paulo 1995; 5 (6)(Supl A):6-8. 